\title{
The Mesolithic at the Danube's Iron Gates: new radiocarbon dates and old stratigraphies
}

\author{
Alexandru Dinu', Andrei Soficaru², Doru Miritoiu3 \\ 1 University of Wisconsin, Madison, USA, adinu@facstaff.wisc.edu \\ 2 The Center for Anthropological Research 'Francisc I. Rainer', Bucharest, Romania, asoficaru@yahoo.com \\ 3 The Center for Anthropological Research 'Francisc I. Rainer', Bucharest, Romania
}

\begin{abstract}
In this paper we present 31 new AMS radiocarbon dates from the Mesolithic Iron Gates sites. The new dates allowed for a total reconsideration of the chronological sequences, and offer new insights for a reinterpretation of both Upper Paleolithic-Mesolithic and Mesolithic-Neolithic developments in the region.
\end{abstract}

IZVLEČEK - V tem članku predstavljamo 31 novih AMS radiokarbonskih datumov iz mezolitskih najdišč na območju Železnih vrat na romunski obali Donave. Novi datumi so omogočili v celoti ponovno pretehtati kronološke sekvence in ponujajo nove vpoglede za ponovno interpretacijo tako mlajšepaleolitsko-mezolitskega kot mezolitsko-neolitskega razvoja $v$ regiji.

KEY WORDS - Tardigravettian; Mesolithic; Neolithic; site stratigraphy

\section{Introduction*}

The construction during the 1960's of the Iron Gates dam across the Danube triggered an intense archaeological survey of the region, which resulted in the discovery of a number of archaeological sites on both sides of the river. The remains uncovered at some of these sites were later associated with a Mesolithic culture called Lepenski Vir in Serbia, and Schela Cladovei in Romania (Fig. 1). Presently all the sites are under water or destroyed by subsequent construction projects, except for the eponymous site of Schela Cladovei.

Although numerous radiocarbon dates are available for the sites on the southern shore of the Danube (Bonsall 1997; Bonsall, Boroneant and Srejović 1996; Bonsall et al. 2000; Bonsall et al. 2004; Bonsall et al. 2002/3; Borić 2001; 2002; 2005; Borić and Miracle 2004; Cook et al. 2002; Radovanović 1996a; Srejovic 1965; 1990) the understanding of the evolutionary trajectory of Lepenski Vir-Schela Cladovei culture has been much restricted by an acute absence of dates from the sites uncovered on the northern shore, for which before 1990 only some 18 dates were available (Paunescu 2000; Radovanović 1996a; 1996b).

After 1990, archaeological excavation restarted at Schela Cladovei, and more dates were published for this site (Bonsall 1997; Bonsall, Boroneant and Srejović 1996; Bonsall et al. 2004; Bonsall et al. 2002/3; Cook et al. 2002).

In this paper we present 31 new AMS radiocarbon dates from the Schela Cladovei culture sites of Razvrata, Icoana, Ostrovul Banului, Ostrovul Mare, and Schela Cladovei (Tab. 1). The implication of these new dates will be discussed in reference to the published stratigraphic information, older dates availa-

\footnotetext{
* It has been acknowledged to us (A. Boroneant, pers. comm.) that additional stratigraphic profiles and a great volume of information about excavations at the sites presented here exist in an unpublished format. This work considers only the published material, and we only hope that in the near future the additional material will be made available in printed form.
} 
ble for the Romanian sites (Tab. 2), and some of the radiocarbon dates from the Serbian sites.

Although some authors (Boroneant 1973a; 1973c; 1980; 1990a; 1990b; 2000b; Boroneant et al. 1995; Boroneant and Boroneat 1983; Boroneant, Craciunescu, and Stinga 1979; Boroneant and Nicolaescu-Plopsor 1990; Voytek and Tringham 1990) have emphasized similarities among the Serbian and Romanian sites, others (Boric 2001; Paunescu 2000; Radovanović 1996a; 1996b; 1999) have made evident a number of differences. It is generally agreed, however, that all Iron Gates Mesolithic sites represent one culture.
It must be underlined that in most previously published maps of the Iron Gates sites, the geographical location of sites at Razvrata and Icoana have been reversed (Bonsall 1997; Bonsall, Boroneant and Srejović 1996; Bonsall et al. 2002/3; Borić 1999; 2001; 2002; 2004; Boroneant 1970; 1990b; Prinz 1987; Radovanović 1996a; 1999; Radovanović and Voytek 1997; Tringham 2000; Voytek and Tringham 1990). Razvrata was located on a small alluvial fan at the left of Mraconia River mouth, right across the site of Hajdučka Vodenica. Icoana was located about 700-800 m downstream (Boroneant 1973c; Paunescu 2000). The exact location of these sites is presented in Figure 2.

\begin{tabular}{|c|c|c|c|c|c|}
\hline $\begin{array}{l}\text { Site } \\
\text { New Dates }\end{array}$ & $\begin{array}{l}\text { Depth } \\
(-) \mathrm{m}\end{array}$ & AA \# & $\begin{array}{c}\text { 14C Age } \\
\text { BP }\end{array}$ & $\begin{array}{c}\text { Cal. } B C \\
\text { range }(1 \sigma)\end{array}$ & Sample \\
\hline Icoana & 1.4 & AA65564 & $9403 \pm 93$ & $8820-8540(67.2 \%)$ & Sus scrofa \\
\hline Icoana & 0.6 & AA67748 & $9247 \pm 89$ & $8570-8330(68.2 \%)$ & Sus scrofa \\
\hline Icoana & 0.9 & AA65558 & $9196 \pm 89$ & $8490-8300(61.3 \%)$ & Sus scrofa \\
\hline Icoana & 1.55 & AA66586 & $9101 \pm 87$ & $8450-8240(68.2 \%)$ & Sus scrofa \\
\hline Icoana & 1.3 & AA67750 & $9044 \pm 88$ & $8350-8180(53.9 \%)$ & Sus scrofa \\
\hline Icoana & 1.6 & AA65565 & $8989 \pm 88$ & $8290-8160(38.1 \%)$ & Sus scrofa \\
\hline Icoana & 1.9 & AA65556 & $8966 \pm 87$ & $8120-7970(35.4 \%)$ & Sus scrofa \\
\hline Icoana & 1.1 & AA65560 & $8955 \pm 73$ & $8120-7980(36.2 \%)$ & Sus scrofa \\
\hline Icoana & 1.65 & AA65566 & $8952 \pm 88$ & $8130-7970(39.0 \%)$ & Sus scrofa \\
\hline Icoana & 1.7 & AA65554 & $8913 \pm 87$ & $8240-7960(68.2 \%)$ & Sus scrofa \\
\hline Icoana & 1.2 & AA65562 & $8907 \pm 98$ & $8250-7940(68.2 \%)$ & Sus scrofa \\
\hline Icoana & 2.1 & AA66377 & $8855 \pm 93$ & $8210-8030(35.3 \%)$ & Sus scrofa \\
\hline Icoana & 1 & AA65559 & $8840 \pm 86$ & $8010-7810(38.5 \%)$ & Sus scrofa \\
\hline Icoana & 1.15 & AA65561 & $8729 \pm 79$ & $7840-7600(61.7 \%)$ & Sus scrofa \\
\hline Icoana & 0.4 & AA66369 & $8702 \pm 86$ & $7830-7590(65.6 \%)$ & Sus scrofa \\
\hline Icoana & 0.5 & AA65547 & $8648 \pm 83$ & $7760-7580(67.5 \%)$ & Sus scrofa \\
\hline Icoana & 1.95 & AA65551 & $8575 \pm 83$ & $7680-7530(68.2 \%)$ & Sus scrofa \\
\hline Icoana & 0.3 & AA66368 & $7604 \pm 76$ & $6530-6390(63.5 \%)$ & human \\
\hline Icoana & 1.25 & AA65563 & $7245 \pm 62$ & $6210-6130(35.8 \%)$ & Sus scrofa \\
\hline Ostrovul Banului & 0.4 & AA66370 & $8219 \pm 87$ & $7350-7080(68.2 \%)$ & Sus scrofa \\
\hline Ostrovul Mare & 1.7 & AA66379 & $7890 \pm 78$ & $6830-6640(52.7 \%)$ & Sus scrofa \\
\hline Razvrata & 2.1 & AA66378 & $8971 \pm 86$ & $8280-8160(34.3 \%)$ & Sus scrofa \\
\hline Razvrata & 1.8 & AA65555 & $8891 \pm 87$ & $8240-7930(68.2 \%)$ & Sus scrofa \\
\hline Schela Cladovei & 1.67 & AA66376 & $8192 \pm 79$ & $7310-7070(62.2 \%)$ & Sus scrofa \\
\hline Schela Cladovei & 1.42 & AA66374 & $8128 \pm 90$ & $7310-7030(68.2 \%)$ & Sus scrofa \\
\hline Schela Cladovei & $0.82-0.87$ & AA67749 & $8065 \pm 79$ & $7150-6900(54.7 \%)$ & Sus scrofa \\
\hline Schela Cladovei & 1.17 & AA66372 & $8056 \pm 80$ & $7090-6820(61.8 \%)$ & Sus scrofa \\
\hline Schela Cladovei & 0.77 & AA66371 & $7975 \pm 80$ & $7050-6770(68.2 \%)$ & Sus scrofa \\
\hline Schela Cladovei & 1.37 & AA66373 & $7956 \pm 78$ & $7030-6750(68.2 \%)$ & Sus scrofa \\
\hline Schela Cladovei & 1.62 & AA66375 & $7921 \pm 78$ & $6840-6680(42.4 \%)$ & Sus scrofa \\
\hline Schela Cladovei & $0.45-0.53$ & AA67751 & $6773 \pm 70$ & $5725-5625(65.2 \%)$ & Sus scrofa \\
\hline
\end{tabular}

Tab. 1. New AMS radiocarbon dates for Iron Gates Mesolithic, Schela Cladovei culture. All samples ran by the Accelerator Mass Spectrometry Laboratory, University of Arizona, Tucson. BC calibration using OxCal. The status of S. scrofa was established in conformity with the DNA analysis results (Dinu 2006; Larson et al. 2007) and compared metrics and morphology (Dinu 2006; Dinu et al. 2006). 


\section{General site characteristics}

Except for Ostrovul Corbului and Schela Cladovei, all Mesolithic sites on the Romanian shore of the Danube were discovered and excavated by Boroneant (Boroneant 1970; 1973a; 1973b; 1973c; 1980; 1990a; 1990b; 2000a; 2000b; Boroneant and Nicolaescu-Plopsor 1990). The Schela Cladovei site was excavated also by British archaeologists between 1990-1994 (Bartosiewicz et al. 1995; Bartosiewicz et al. 2001; Bonsall 1997; Bonsall, Boroneant and Srejović 1996; Bonsall et al. 2000; Bonsall et al. 2004; Bonsall et al. 2002/3; Cook et al. 2002).

Ostrovul Corbului at Botul Cliuciului was surveyed in 1933 by a team led by Dumitru Berciu; the actual site was discovered by Marin Nica in 1970, and excavated between 1970-1984 by Petre Roman, Alexandru Paunescu and Florea Mogoseanu (Mogosea-

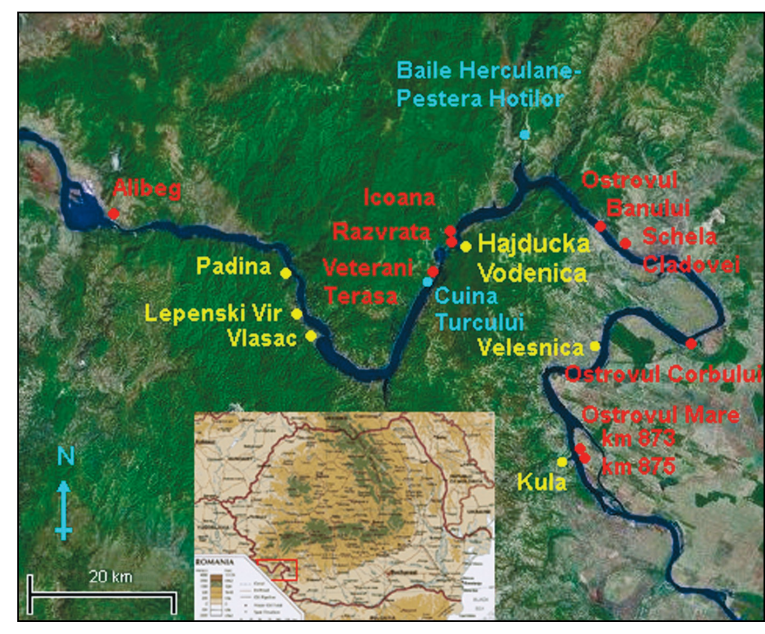

Fig. 1. Iron Gates sites associated with Mesolithic remains. Red: Schela Cladovei culture. Yellow: Lepenski Vir culture. Blue: other sites on the Romanian shore not associated with the Mesolithic Iron Gates, but mentioned in this paper.

\begin{tabular}{|c|c|c|c|c|c|}
\hline $\begin{array}{l}\text { Site } \\
\text { Old Dates }\end{array}$ & Depth & AA\# & $\begin{array}{c}\text { 14C Age } \\
\text { BP }\end{array}$ & $\begin{array}{l}\text { Cal. } B C \\
\text { range }(1 \sigma)\end{array}$ & Sample \\
\hline Alibeg & NA & NA & NA & $8410 \pm 100 \mathrm{BC}$ & \\
\hline Alibeg & NA & Bln-1193 & $7195 \pm 100$ & $6120-5980(46.7 \%)$ & charcoal \\
\hline Icoana & 0.5 & Bln-1078 & $8605 \pm 250$ & $8200-7350(68.2 \%)$ & charcoal \\
\hline Icoana & 2.1 & Bln-1077 & $8265 \pm 100$ & $7460-7170(68.2 \%)$ & charcoal \\
\hline Icoana & NA & Bonn 2 & $8070 \pm 130$ & $7190-6770$ (66.7\%) & charcoal \\
\hline Icoana & NA & Bonn 3 & $8010 \pm 120$ & $7070-6740(64.4 \%)$ & charcoal \\
\hline Icoana & NA & Bonn 4 & $7660 \pm 110$ & $6610-6420(65.9 \%)$ & charcoal \\
\hline Icoana & NA & Bln-1056 & $7445 \pm 80$ & $6400-6230(68.2 \%)$ & charcoal \\
\hline Icoana & NA & Bonn 1 & $5830 \pm 120$ & $4840-4540(68.2 \%)$ & charcoal \\
\hline Ostrovul Banului & NA & Bln-1080 & $8040 \pm 160$ & $7180-6690(68.2 \%)$ & charcoal \\
\hline Ostrovul Banului & NA & Bln-1079 & $7565 \pm 100$ & $6510-6340(56.2 \%)$ & charcoal \\
\hline Ostrovul Corbului & $4.50-4.53$ & SMU-587 & $8093 \pm 237$ & $7350-6650(68.2 \%)$ & charcoal \\
\hline Ostrovul Corbului & $4.02-412$ & SMU-588 & $7827 \pm 237$ & $7050-6450(68.2 \%)$ & charcoal \\
\hline Ostrovul Corbului & $4.20-4.38$ & Bln-2135 & $7710 \pm 80$ & $6610-6460(68.2 \%)$ & charcoal \\
\hline Ostrovul Corbului & $4.20-4.39$ & $B \ln -2135 A$ & $7695 \pm 80$ & $6600-6460(68.2 \%)$ & charcoal \\
\hline Ostrovul Corbului & 4.23 & GrN-12675 & $7640 \pm 80$ & $6570-6430(65.5 \%)$ & charcoal \\
\hline Razvrata & NA & Bln-1057 & $7690 \pm 70$ & $6590-6460(68.2 \%)$ & charcoal \\
\hline Schela Cladovei & NA & OxA-4384 & $8570 \pm 105$ & $7691-7496 \quad N A$ & Human \\
\hline Schela Cladovei & NA & OxA-4379 & $8550 \pm 105$ & $7588-7490 \quad N A$ & Human \\
\hline Schela Cladovei & NA & OxA-4385 & $8510 \pm 105$ & 7577-7443 NA & Human \\
\hline Schela Cladovei & NA & OxA-4382 & $8490 \pm 110$ & $7573-7434 \quad N A$ & Human \\
\hline Schela Cladovei & NA & OxA-4380 & $8460 \pm 110$ & $7547-7425 \quad N A$ & Human \\
\hline Schela Cladovei & NA & OxA-4378 & $8415 \pm 100$ & $7535-7319 \quad N A$ & Human \\
\hline Schela Cladovei & NA & OxA-4381 & $8400 \pm 115$ & $7535-7303$ NA & Human \\
\hline Schela Cladovei & NA & Poz-5206 & $8300 \pm 50$ & $7480-7300(68.2 \%)$ & Human \\
\hline Schela Cladovei & NA & OxA-4383 & $8290 \pm 105$ & $7479-7093 \quad \mathrm{NA}$ & Human \\
\hline Cuina Turcului & NA & $\mathrm{B} \ln -8 \mathrm{O} 2$ & & $8175 \pm 200 \mathrm{BC}$ & charcoal \\
\hline Cuina Turcului & NA & Bln-803 & & $10650 \pm 120 \mathrm{BC}$ & charcoal \\
\hline Cuina Turcului & NA & Bln-804 & & $10100 \pm 120 \mathrm{BC}$ & charcoal \\
\hline
\end{tabular}

Tab. 2. Old radiocarbon dates for Iron Gates Mesolithic, Schela Cladovei culture. BC calibration using OxCal (The date was offered in this form by V. Boroneant (Boroneant 2000b.86). 


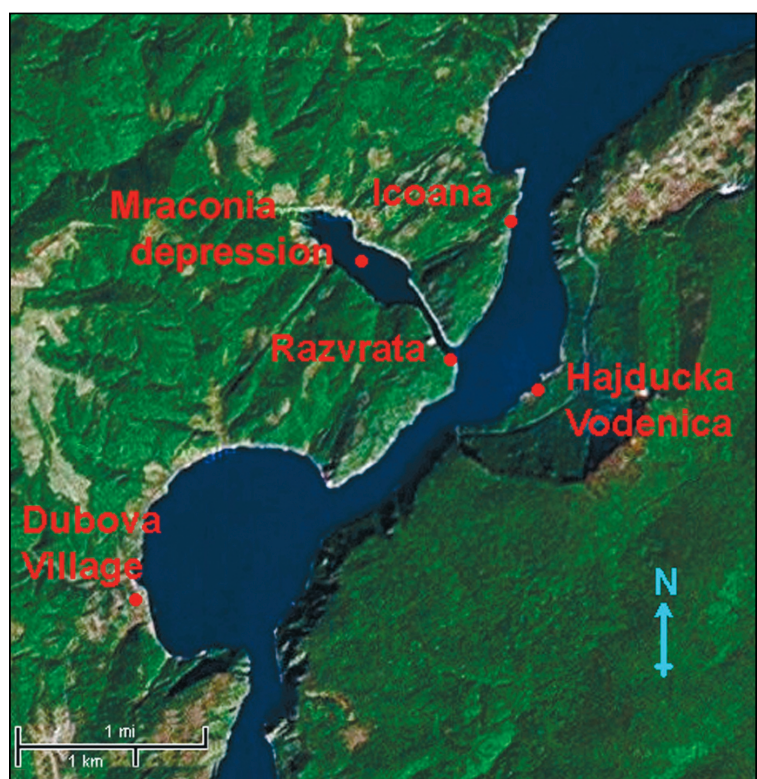

Fig. 2. Exact location of Icoana and Razvrata sites.

nu 1978; Necrasov and Botezatu 1981; Paunescu 1990; 2000; Roman 1987).

Schela Cladovei was discovered by Misu Davidescu, who excavated a portion of the Neolithic Starčevo area of the site (Davidescu 1965).

There are a number of characteristics common to all Mesolithic Schela Cladovei sites. As a general pattern, Schela Cladovei sites can be divided into two categories: those located within the Gorge: AlibegPescari, Veterani Terasa, Razvrata, and Icoana; and a second group located downstream from the Gorges: Ostrovul Banului-Gura Vaii, Schela Cladovei, Ostrovul Corbului, and Ostrovul Mare.

All of the excavated Schela Cladovei culture sites located in the canyon were found in places where the limestone mountain wall sandwiches through basalt directly into the Danube's waters, forming extensive karstic phenomena. There are a good number of grottos and cave formations right on the Danube shore or no farther than 10-60 $\mathrm{m}$ from the water: Gaura Livaditei, Pazariste, Liubcova, Gaura Chindiei I, Gaura Chindiei II, Proluca lui Climente, Gaura cu Musca, Ponicova, Cuina Turcului, Pestera Fluturilor, Pestera lui Caramfil, and Pestera Veterani. None of the Mesolithic sites, however, were located in caves (Boroneant 2000a). Without exception, the sites were found only in the open air, on the Danube shore, next to the water, in most cases below the modern flood level on very low land, sandy and humid, even swampy. According to geological and hydrological studies of the region, it appears that flo- oding of the Danube shore was equally frequent by the time of the Mesolithic occupation (C.S.A. 1967; Grupul de Cercetari Complexe 1976; I.G.G.A.R.S.R. 1969).

The sites belonging to the second group outside the Gorge are located on islands, with the exception of Schela Cladovei itself. Before the formation of the lake, however, these islands had always been divided by the Danube's northern shore by a very narrow secondary river branch. These branches were rather easy to cross, and the fishing was exceptionally good. Generally, the channels were not very deep, the water flowed slowly, and during some less rainy years the water drained off almost entirely.

One other characteristic of all the sites is that their location was such as to permit easy access to the nearest best fishing and hunting sites regardless the nature of the terrain surrounding the site within a radius of a 30-190 minute walk. This would allow the inhabitants immediate and easy access to terrestrial resources, raw material and, in all cases, better defence.

\section{Sites, stratigraphies, and problems}

Regrettably, Boroneant did not publish excavation maps for any of the sites except Schela Cladovei (Boroneant 2000b.277). As a consequence, at present it is impossible to determine the relationship between artefacts uncovered in different excavation sections, other than considering the depth inscribed on them. Because the stratigraphic information is also scant and a datum was never used except at Ostrovul Corbului (Paunescu 1990), presently, comparing artefacts from the same site and excavation depth, but different excavation sections becomes nonsense, a problem signalled also by others (Paunescu 2000). The new radiocarbon dates presented here were selected and therefore considered only according to the depth inscribed on them.

Due to the inconsistent terminology used for stratigraphic description and analysis, the overall picture of cultural sequences at all sites is confusing. Some authors (Prinz 1987; Radovanović 1996a; Tringham 2000) advanced periodization models of the northern Danube shore sites relying mostly on information offered by Boroneant, who appears to have been strongly influenced by the periodization of the site at Lepenski Vir, and attempted to apply it indiscriminately to the Romanian sites (Boroneant 1973c; 1990b). Others (Tringham 2000), including some 
Romanian authors (Lazarovici 1979), mainly specialized in the Neolithic period.

Some (Paunescu 2000) based their hypothesis on their own lithic analysis, almost excluding any other available material. Finally, some archaeologists presented models based on their own excavations and a synthesis of the previously published material ( $\mathrm{La}$ zarovici 1979; Mogoseanu 1978).

The inconsistency in using the same archaeological terms by all the Romanian authors is extremely confusing and it has deep theoretical roots (Boroneant and Dinu 2007), but it was accentuated by a paper published in the mid 1960's by the one of the most influential Romanian archaeologists (NicolaescuPlopsor 1965). Following the opinions expressed in this publication, Boroneant uses indiscriminately the term 'Epipaleolithic' in reference to both the actual Epipalaeolithic and the Mesolithic periods at Iron Gates. Fortunately, some authors attempted to rectify this problem (Mogoseanu 1978; Paunescu 1990; 2000). The most notable attempt in this direction comes from Paunescu:

"Faza evoluata a culturii gravetiene apartinind epiapaleoliticului, cunoscuta sub denumirea de tardigravetian de tip mediteranean, este representata prin cele 9 puncte descoperite numai in zona Portilor de Fier.

$$
\therefore
$$

Mezoliticul din teritoriul cuprins intre Carpati si Dunare este cunoscut prin cele doua culturi care au evoluat parallel sau partial parallel, in doua zone diferite. Prima - cea tardenoasiana - este atestata in nord-estul si nordul Munteniei ... Cea de-a doua cultura mezolitica - cultura Schela Cladovei - este representata de cele 8 puncte descoperite prin sapaturi sistematice in zona Portilor de Fier ..." (Paunescu 2000.40)

(The evolved phase of the Gravettian culture belonging to the Epipaleolithic, and known as Tardigravettian of Mediterranean type is represented by the 9 sites discovered only in the Iron Gates area. $\therefore$

The Mesolithic of the territory enclosed by the Carpathian Mountains and the Danube River is known by the cultures that evolved in parallel or partly in parallel, in two different areas. The first - the Tardenoisian - is attested in the northern and northeastern Muntenia ... The second Mesolithic culture Schela Cladovei culture - is represented by the 8 sites uncovered by systematic excavations in the Iron Gates region...) (Our translation)
Therefore, Paunescu makes a clear distinction between the Epipalaeolithic as the final stage of the Upper Palaeolithic, and the Mesolithic period at Iron Gates, but mostly as terminology, and less as a concept (Boroneant and Dinu 2007). The general image is further complicated by the use of alternative names for the cultural sequences at Iron Gates (Boroneant 1999):

(1) Final Epi-Gravettian - or Proto-Clisurean, or ProtoRomanellian at site Climente I Cave.

(2) Late Epi-Gravettian - Clisurean or Romanellian, or Tardigravettian (Paunescu 1970; Paunescu 1987) Romanello- Azilian at Climente II, Cuina Turcului I and II, Ostrovul Banului I-IIIa, comprising four stages of development.

(3) Mesolithic Schela Cladovei, comprising four stages of development (Boroneant 1973c).

In relation to the above classification, it is interesting to notice that logically, the late phase of Epi-Gravettian would sequentially occur before, not after the final phase of the same period, as the Proto-Clisurean occurs before the Clisurean. No further details were published by Boroneant, so it is not possible to know if the stratigraphies published by him follow the same rational. For instance, the first phase of his periodization of Schela Cladovei culture is characterize as the oldest phase at both Veterani Terrace and Veterani Cave, and associated with "la phase finale du romanellien" (Boroneant 1973c.15). On the other hand, no remains associated with Schela Cladovei culture were uncovered at Cave Veterani (Boroneant 2000a; 2000b; Paunescu 2000), although Boroneant lists the stratigraphic sequence of the cave as Palaeolithic, Epipalaeolithic (Clisurean), Mesolithic, Neolithic (Boroneant 2000a.90) with no further explanations.

For a better understanding of the problems related to site stratigraphy, terminology, as well as to the implications of the new radiocarbon dates presented in this paper it is therefore necessary to offer a brief presentation of the sites and their stratigraphies.

\section{Pescari-Alibeg}

This is the most western Schela Cladovei culture site on the northern shore of the Danube. According to Paunescu (Boroneant 1973c; 2000b; Paunescu 2001) the site was located on the south-eastern end of the village of Pescari (Coronini), at the base of Redut Hill, on Alibeg Creek. Paunescu also states that it was located on a portion subject to Danube flooding, and that a good part of the site was destroyed 
by the river prior to and during excavations. There was a small alluvial peninsula at the mouth of Alibeg Creek, where this site was located (Boroneant 2000b).

Boroneant discovered the site in 1968, but excavations did not started until 1971 when the water level was already covering part of it. There are no published general maps of the area or site distribution maps. Excavation information is scant, and very little material was recovered. Excavations comprised eight sections of an unspecified area. The results of

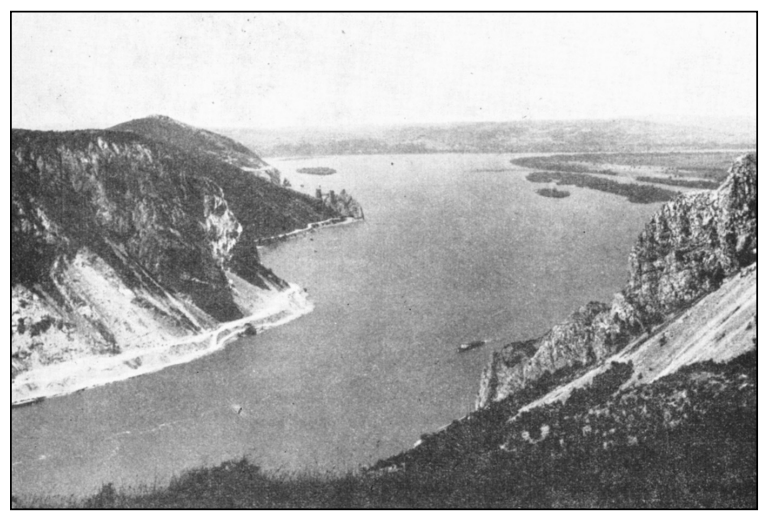

Fig. 3. Old photo of the Danube at the entrance to Pescari-Alibeg Canyon, seen from the Romanian shore. The river flows right to left. Photo courtesy of the Institute of Geography, Bucharest.

excavation were briefly mentioned over the years by Boroneant (Boroneant 1973a; 1973c; 1980), and to a larger degree at a more recent date (Boroneant 2000b; Paunescu 2000).

Boroneant suggests that there was one level of habitation, belonging to a late phase of Schela Cladovei culture varying between $0.60 \mathrm{~m}$ to $1.00 \mathrm{~m}$ in thickness (Boroneant 2000b; Paunescu 2001). He associates the Mesolithic at Alibeg with:

“... une phase finale d'Icoana, horizon I, qui poursuit son évolution jusqu'au commencement de l'habitat d'Alibeg." (Boroneant 1973a.

Paunescu (Paunescu 2001) advanced the hypothesis that this level had to be associated with two cultural layers: one belonging to late Mesolithic Schela Cladovei, and an Early Neolithic Starčevo-Criş just above it, with no archaeological sterile in between.
Paunescu was, however, very cautious in advancing this hypothesis, due to the fact that Boroneant did not separate the findings for each cultural layer.

\section{Veterani Terasa}

The problems posed by this site are presently extremely difficult to address. It was located precisely in front of Veterani Cave, at the base of Ciucarul Mare Mountain. There was a small alluvial deposit, suggesting that at one time a small stream probably flowed from the cave (Paunescu 2000). Boroneant discovered the site in 1968 , but excavations started only in 1969. Although earlier and later cultural layers were uncovered in the cave, Mesolithic material was not found; moreover, all the cultural strata were extremely disturbed and mixed up.

According to some accounts (Paunescu 2000.376) excavations of the Veterani Cave yielded remains associated with the Medieval period, the Roman period, Neolithic Cotofeni and Starčevo-Criş, and Tardigravettian (Boroneant 2000a; Paunescu 2000); no Mesolithic remains were found, and the stratigraphy appears to have been extremely disturbed.

A contrasting image is offered elsewhere; the cultural sequences identified in the cave are listed as Palaeolithic, Epipalaeolithic (Clisurean), Mesolithic, Neolithic Starčevo-Criş, Neolithic Cotofeni, Hallstatt (Basarabi), Dacian, Daco-Roman, Byzantine and Medieval, modern (Boroneat 2000a.90). The stratigraphy is also presented as extremely disturbed.

Logically it is impossible to understand why a group of people would chose to face meteorological discom-

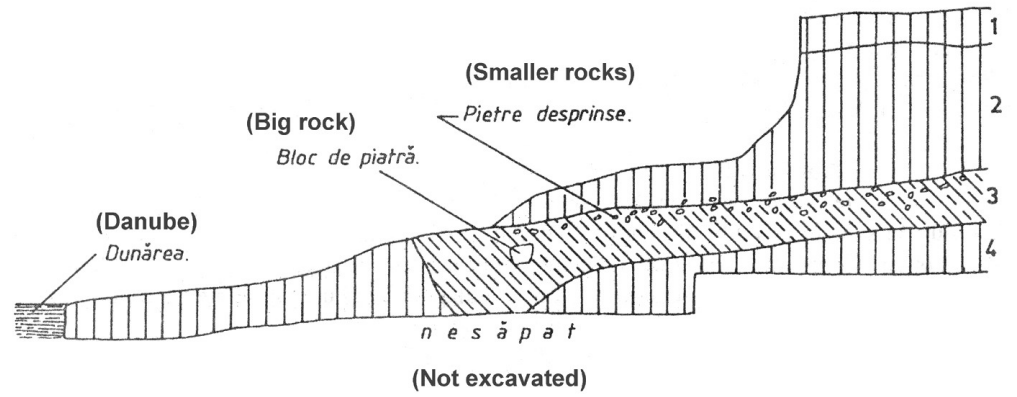

Fig. 4. Profile of Section II $-\mathrm{NW}$ at Alibeg (Boroneant 1973c; 2000b; Paunescu 2001): 1. recent humus of about 0.40m; 2. sandy yellowish soil, sterile archaeological of about 0.40-1.65m; 3. blackbrown soil, Mesolithic occupation of about 0.60-1.00m; 4. yellow soil with lime stone penetration 0.60-0.90m; Boroneant (1973c.7) uses neither Epipalaeolithic or Mesolithic in defining level 3. Instead, he simply named it 'couche culturelle'. A scale was not originally published by (Boroneanţ 1973c), but added by Paunescu (Paunescu 2001). 


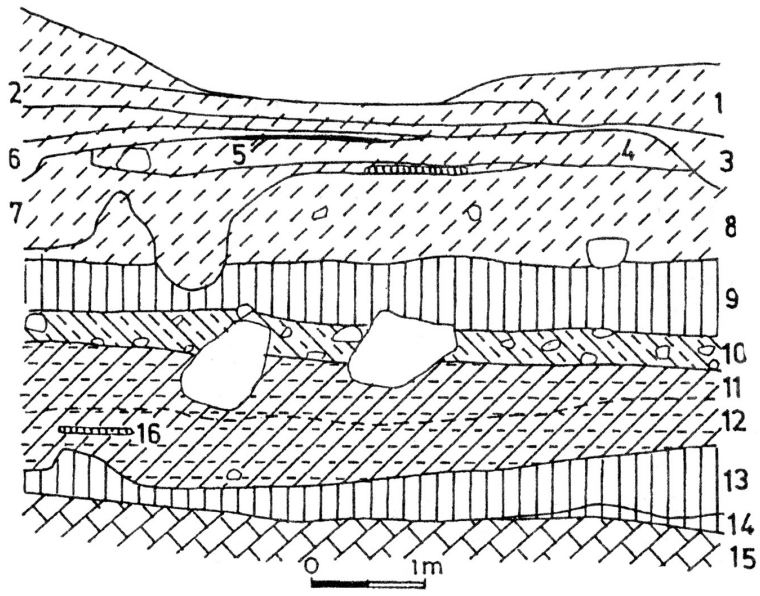

Fig. 5. North profile, Section IV, Veterani Terasa (Boroneant 1973c; 2000b; Paunescu 2000). Paunescu (2000.376-377) identifies the following strata: 1. debris of about 0.05-0.40m; 2. ashes of about 0.05-0.12m; 3. sandy yellow soil of about 0.03$0.05 \mathrm{~m}$; 4. ashy yellow soil of about 0.20-0.30m; 5. black soil of about 0.05-1.00m; 6. yellow-grey soil of about 0.05-0.90m; 7. yellow soil of about 0.45-0.65m; 8. yellow soil, Salcuta culture of about 0.25-0.35m; 9. dark brown soil of about 0.30$0.65 \mathrm{~m}$ - archaeologically sterile; 10. light brown soil of about 0.40-0.65m - Mesolithic Schela Cladovei culture; 11. gravel and sand of about 0.15$0.60 m$ - Level II of Tardigravettian of Mediterranean type; 12. sand lens of about 0.03-0.05m - Level I Tardigravettian of Mediterranean type; 13. limestone bed. Paunescu offers no information for layers 14 and 15; however, level 15 is defined as bedrock, levels 13 and 14 as archaeologically sterile, and levels 1-8 as post - Paleolithic deposition (Paunescu 2000.377). Scale was offered by V. Boroneant (1973c).

fort living in the open, in front of the cave, if a natural shelter was available only a few steps away. On the other hand, it is more likely that earlier and later inhabitants of the cave did throw a great quantity of refuse at and below the entrance. A great part of this refuse washed away by rain, as well as other refuse from inside the cave carried by the ancient stream, would have naturally ended on the terrace. It appears that the excavator may have not been aware of this problem. Moreover, the stratigraphic sequence of the terrace (Boroneant 1973c; 2000b; Paunescu $2000)$ is unclear.

No perforated antler tools characteristic of Mesolithic Schela Cladovei culture were found at this site.

In Paunescu's interpretation (2000.377), there appears to be two Epipalaeolithic- Tardigravettian excavation levels 11 and 12, and a Mesolithic Schela Cladovei excavation level 10. He mentions the re- mains of a hearth, which is associated with the Tardigravettian period, excavation level 12.

Boroneant describes excavation level 10 at Veterani Terasa as "terre jaune comportant des rares traces épipaleolithiques" and does not mention any cultural remains for excavation levels 11 and 12 (Boroneant 2000b.271). There are no radiocarbon dates from this site.

\section{Razvrata}

Before it flows into the Danube, the Mraconia River forms a bassinet (a small semi-enclosure) named Mraconia Depression, of about $1.5 \mathrm{~km}$ long and $400 \mathrm{~m}$ wide behind Ciucarul Mic Mountain. It then bores through the mountain through a short defile of about $500 \mathrm{~m}$ long and, before the formation of the lake of the hydroelectric plant, diverted into the Danube, bringing a great amount of alluvium with it. This alluvium built up two fenny peninsulas at each side of the river mouth. It was on the smaller peninsula that the site of Razvrata was located.

The site was already in great part destroyed by the Danube by the time Boroneant (1973a) located it 1967. Excavations took place in 1967 and 1968. Five trenches were dug. There are no details of the area excavated, no excavation plans, or site distribution maps. Two layers of Schela Cladovei culture were re-

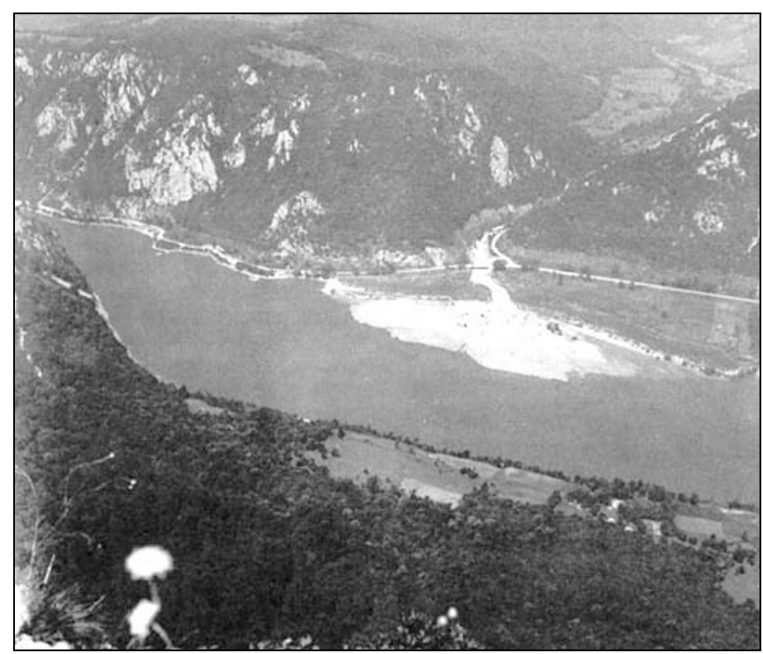

Fig. 6. Photo of Mraconia River alluvial deposits in the Danube, before the building of the dam. The Razvrata site was located on the left (of the photo) alluvial section. Hajdučka Vodenica was located just opposite the Mraconia River mouth. The Danube flows left to right. Upper right: Mraconia Depression, a possible location of a base-site for IcoanaRazvrata outpost sites. (Courtesy of Ivana Radovanović) 
vealed. There is one published stratigraphy of the SE wall of section $\mathrm{S} I$.

At Razvrata it is not clear if the explanation offered by the published stratigraphy refers to the second phase of Schela Cladovei culture, or generally to the second cultural level of the site. Boroneant (1973c. 9) simply refers to the two cultural levels as 'Epipaleolithic I and II'. Paunescu (2000.393) defines the lower cultural level as 'Level I Epipaleolithic Tardigravettian', and the upper cultural level as 'Level II Mesolithic'.

\section{Icoana}

The site was located on a narrow strip of the Danube bank at the foot of Ciucarul Mic. It appears that the width of this strip was only of about $6 \mathrm{~m}$ (V. Boroneant, personal communication). Information about the exact location of the site varies. Paunescu (2000. 394) gives a distance of $600 \mathrm{~m}$ east of Razvrata; Radovanović (1996a.324) thinks that this distance is about $200 \mathrm{~m}$; Boroneant (1973c.8) refers to "quelques centaines de mètres". In any case, the exact location of the site is known due to a landmark: an icon mounted in the wall of the mountain after the formation of the artificial lake.

According to Boroneant (personal communication), there was a feeble stream of water springing from the mountain wall. The site produced a large amount of archaeological material, especially faunal remains (Bolomey 1973).

According to the published stratigraphy of Section II (Boroneant 1973c; 2000b; Paunescu 2000), there are two Mesolithic Schela Cladovei cultural levels.

Archaeologically, from upper to lower it was possible to distinguish the following levels of site occupation:

Very little can be said about the cultural evolution of the site. As seen in Table 1, there is a sharp discrepancy between the depth inscribed on the samples and the results obtained by the dating of the samples. The situation is not new: the only old dates for which depths were mentioned showed an age of $7460-7170 \mathrm{BC}$ for a depth of $2.1 \mathrm{~m}$, and 8200-7350 $\mathrm{BC}$ for a depth of $0.5 \mathrm{~m}$ (Paunescu 2000.407). It may be that at the time, Boroneant may have not noticed the difference, and therefore did not offer any details about the samples' cultural levels of provenance. Also, according to Boroneanţ's published stratigraphy, at a depth of $-0.30 \mathrm{~m}$ there should

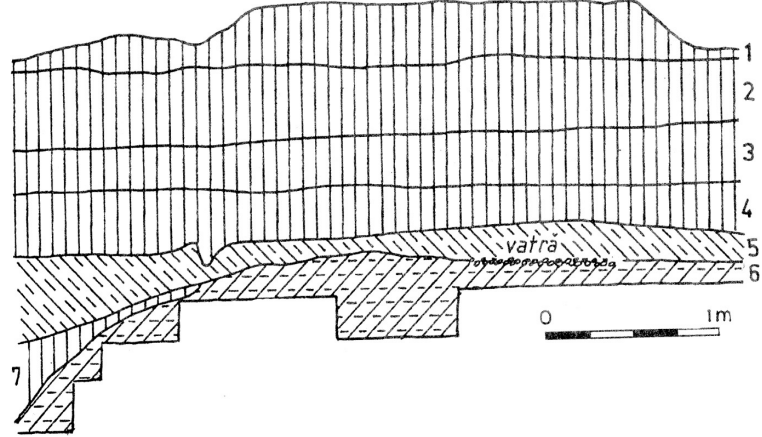

Fig. 7. Southeast profile of Section I, Razvrata (Boroneant 1973c; 2000b; Paunescu 2000): 1. alluvial sand of about 0.05-0.30m; 2. brown-black humus of about 0.35-0.40m; 3. soil light yellow of about 0.20-0.30m; 4. black soil of about 0.17-0.35; 5. light-grey soil, Level II Mesolithic Schela Cladovei Culture of about 0.14-0.34m; 6. yellow sandy soil Level I Tardigravettian of Mediterranean type of about 0.35m; 7. brown-yellow soil. Levels 1-4 are listed as archaeologically sterile. $V$. Boroneant refers to layer 5 as 'epipaleolithique II' and layer 6 as 'epipaleolithique I' (Boroneant 1973c.5). No scale is offered originally by Boroneant (Boroneant 1973c), but Paunescu adds one (Paunescu 2000).

have been a layer associated with Neolithic StarčevoCriş culture, separated by the Mesolithic layers by some $1.00 \mathrm{~m}$ of deposition. The stratum was extremely disturbed (Boroneant, personal communication; Boroneant field notes). However, the human sample AA66368 (Tab. 1) inscribed by Boroneant as IC. 1969 SVII $-0.30 \mathrm{~m}$ produced a date undoubtedly associated with the Mesolithic Schela Cladovei culture occupation of the site, also confirmed by the morphological and metrical analysis comparative to other Mesolithic Schela Cladovei human remains held

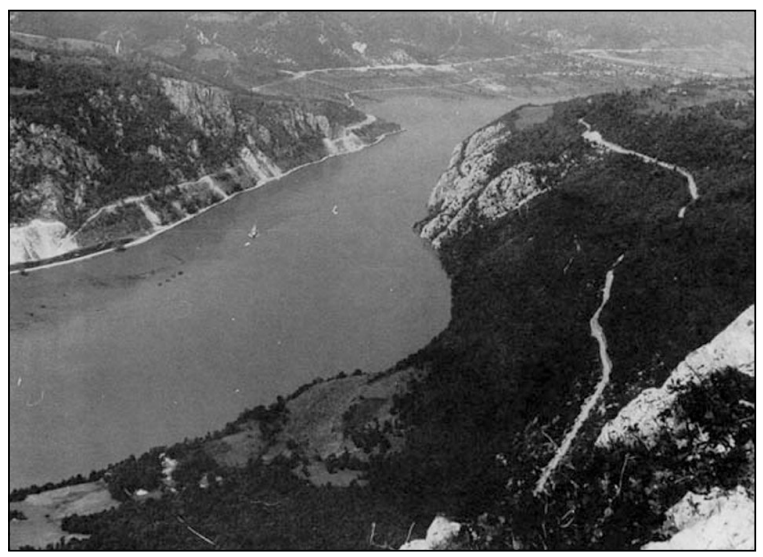

Fig. 8. Old photo of the Danube's left bank at Icoana before the construction of the dam, seen from the Serbian bank. The Hajducka Vodenica location was in the lower left corner of the picture. The Danube flows left to right. Courtesy of Ivana Radovanović. 
Fig. 9. The West profile of Section I, Icoana (Boroneant 1973c; 2000b; Paunescu 2000): 1. mass of recently fallen rocks of about $020-0.87 \mathrm{~m} ; 2$. lightbrown soil, Starčevo-Cris of about 0.10-0.28m; 3 . grayish-black soil of about 0.17-0.33m - Level IIb Mesolithic Schela Cladovei; 4. grey yellow soil of about 0.18-0.75m Level IIa Mesolithic Schela Cladovei; 5. yellow soil, sterile of about $0.25-0.57 \mathrm{~m}$;

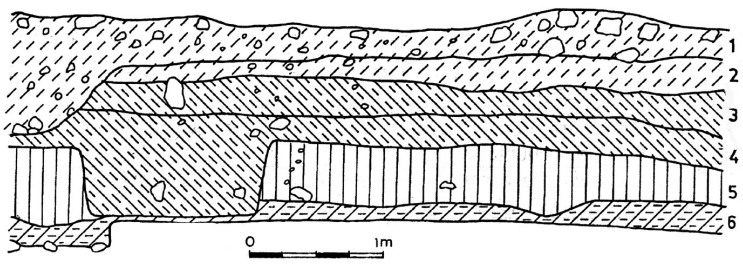
6. grey soil of about 0.15m - Level I Tardigravettian of Mediterranean type. Boroneant (1973c.9) only refers to layers 3 and 6 simply as Epipalaeolithic. A scale was not originally offered by Boroneant (Boroneant 1973c), but Paunescu (2000) adds one.

at the Institute of Anthropology 'Rainer' (Miritoiu, personal communication) in Bucharest (Miritoiu, Sultana and Soficaru 2004) (Tab. 3).

This discrepancy may suggest that levels of occupations at the same depth on different excavation sections belong to different phases of site evolution. If this were true, it may be that the periodization and chronologies offered by Boroneanț may be subject to reinterpretation. The circumstances are aggravated by the fact that no datum was used, and that the nia. Not mentioned in the literature previously published is the fact that, at this point, directly across the Danube, the small River Jidostita disperses its waters. Before the formation of the hydroelectric plant, the Jidostita formed an alluvial fen advancing far into the river and considerably narrowing the distance to the island, making it easily accessible.

The site was located on the south end of the island, which was flooded 2 or 3 months of the year. Presently only a small portion of the island remains excavation depth was measured individually for each section from the ground level down; according to pictures taken by the excavator (Boroneant 1970), the terrain was far from horizontally levelled, and such a method of depth measurement would offer strongly inaccurate premises for comparison. Most regrettably, at this point it is simply impossible to advance any speculations regarding the stratigraphy of the excavated sections.

Boroneanţ (2000b.275) only mentions two layers of Epipalaeolithic and one layer of Neolithic Starčevo. On the same stratigraphic profile, Paunescu (2000.395) notes a cultural level I Tardigravettian, a cultural level IIa Schela Cladovei, and a level IIb Schela Cladovei.

\section{Ostrovul Banului - Gura Vaii}

The site was located on the island of Ostrovul Banului, precisely vis-à-vis the village of Gura Vaii. There was actually a group of three islands, of which only Ostrovul Banului belonged to Roma-

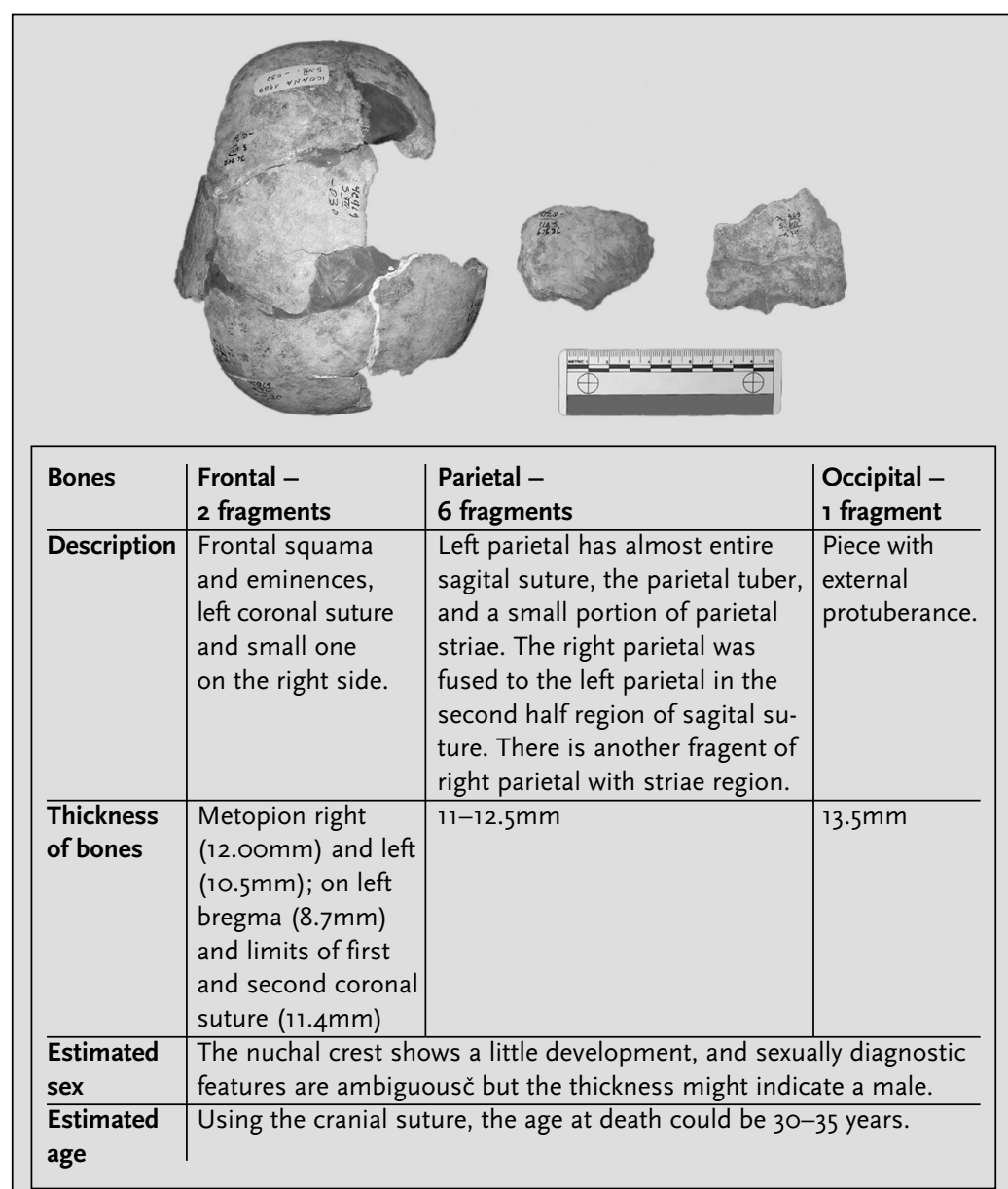

BUIKSTRA J. E. \& UBELAKER D. H. (eds.), 1994. Standards for Data Collection from Human Skeletal Remains. Arkansas Archaeological Survey Research Series, no. 44. WHITE T. D. 1991. Human Osteology. San Diego.

Tab. 3. Icoana. Human skull and related morphological data. 
above the water level. The excavations were begun in 1966, and performed by Petre Roman for the upper, post Mesolithic period, and by Boroneant for the Mesolithic and earlier periods (A. Boroneant, $V$. Boroneant, personal communication). Boroneant excavated six trenches of an unknown area. No site distribution map has been published.

Paunescu advances the hypothesis that the Mesolithic Schela Cladovei found at Ostrovul Banului represents a very late phase of this culture, but some doubts may arise from the reliability of the ${ }^{14} \mathrm{C}$ dates (2000.391). Concerning the archaeological stratigraphy, Paunescu (2001.381) identifies the following cultural levels from upper to lower. The stratigraphy at Ostrovul Banului is problematic as a result of the fact that there are two strata associated, according to lithic typologies, with pre-Mesolithic cultures (BOroneant 2000b; Mogoseanu 1978; Paunescu 2000).

Some authors (Boroneant 1973c.8) simply noted the stratigraphy at Ostrovul Banului as 'Epipaleolithic I' (the oldest), 'Epipaleolithic II', 'Epipaleolithic IIIa' (oldest Mesolithic Schela Cladovei?), and 'Epipaleolithic IIIb' (youngest Mesolithic Schela Cladovei?). Others (Paunescu 2000.382) describe the stratigraphic sequence at Ostrovul Banului as cultural levels I (the oldest) and II Tardigravettian of Mediterranean type, and level III and IV as Mesolithic Schela Cladovei. Yet others (Mogoseanu 1978), referring only to the pre-Mesolithic layers, use the term 'RomanelloAzilian'.

Typologically, the stone tools from the pre-Mesolithic levels at Ostrovul Banului were thought to be identical with those at Cuina Turcului (Paunescu 1970; 2000), a cave situated on the Romanian Shore of the Danube Canyon, less than $200 \mathrm{~m}$ from Veterani Terasa (Fig. 2). The confusion is accentuated by the radiocarbon dates for the tool assemblages from Cuina Turcului, of $10650 \pm 120 \mathrm{BC}, 10100 \pm 120 \mathrm{BC}$, and one date of $8175 \pm 200 \mathrm{BC}$ (Mogoseanu 1978.339) and a possible relation with the proximate site of Baile Herculane-Pestera Hotilor on the Danube's tributary Cerna River (Fig. 1), dated 11 460-11310 BC $(1 \sigma)$ (Paunescu 2000a.146). Mogoseanu cautiously underlines the estimated 2000 year difference between these dates, if Ostrovul Banului is to be considered one of the most recent pre-Mesolithic Schela Cladovei culture sites; at Iron Gates sites, dates of about $8000 \mathrm{BC}$ are associated with Mesolithic Schela Cladovei assemblages. The dates from Ostrovul $\mathrm{Ba}$ nului and Cuina Turcului will be discussed in more detail in a subsequent section of this paper.

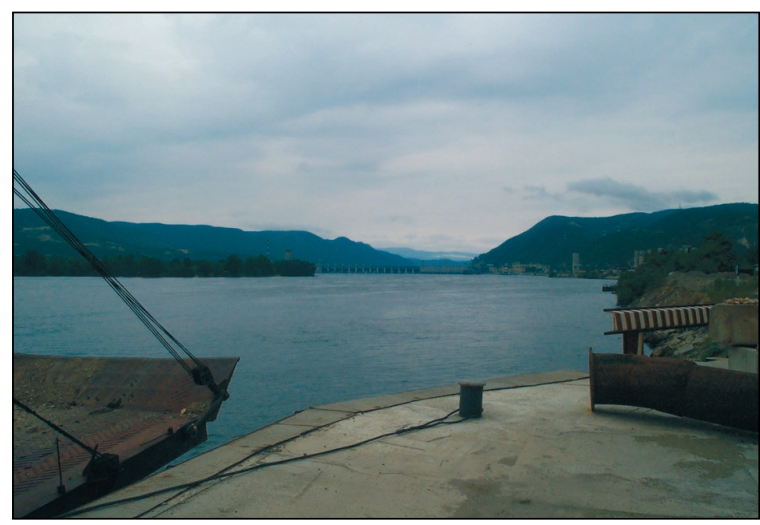

Fig. 10. The Island of Ostrovul Banului, medianleft. In the background the 'Iron Gates I' dam.

Samples associated with Mesolithic Schela Cladovei culture remains at Ostrovul Banului yielded dates between 6300-7300 BC (Tabs. 1, 2). As a consequence, according to our present state of knowledge, it is almost impossible to outline a temporal framework for the ending of Tardigravettian and the beginning of the Mesolithic Schela Cladovei at Ostrovul Banului; on the other hand, it seems unlikely that a Tardigravettian group would have survived that late only at Ostrovul Banului, surrounded by Mesolithic Schela Cladovei groups. Attempts to parallel pre-Mesolithic Schela Cladovei developments with other Iron Gates sites like Cuina Turcului and Baile Herculane - Pestera Hotilor (Boroneant 1973a; 1973c; 2000a; 2000b; Prinz 1987; Radovanović 1996a; 1996b; Tringham 2000) remain problematic (Mogoseanu 1978; Pauпеsси 2000).

As a parenthesis, it must be noted that no Mesolithic Schela Cladovei remains have been uncovered at Baile Herculane-Pestera Hotilor (Bitiri 1959; Nicolaescu-Plopsor 1959; Nicolaescu-Plopsor and Comsa 1957; Nicolaescu-Plopsor et al. 1957; NicolaescuPlopsor and Paunescu 1961; Paunescu 2001a) or at Cuina Turcului (Paunescu 1970; 2000).

\section{Schela Cladovei}

Given the archaeological material uncovered, this is the most important Schela Cladovei culture site. The site is located in Turnu Severin, at the SW end of the city. Although located directly on the bank of the Danube, prior and after the construction of the dam it was less affected by river flooding and increases in the water level compared to any of the other sites because the bank was higher. Technically, the location is still part of the Iron Gates, but in fact it is placed downstream of Gura Vaii point, where the river valley widens and the current slows. There was rela- 


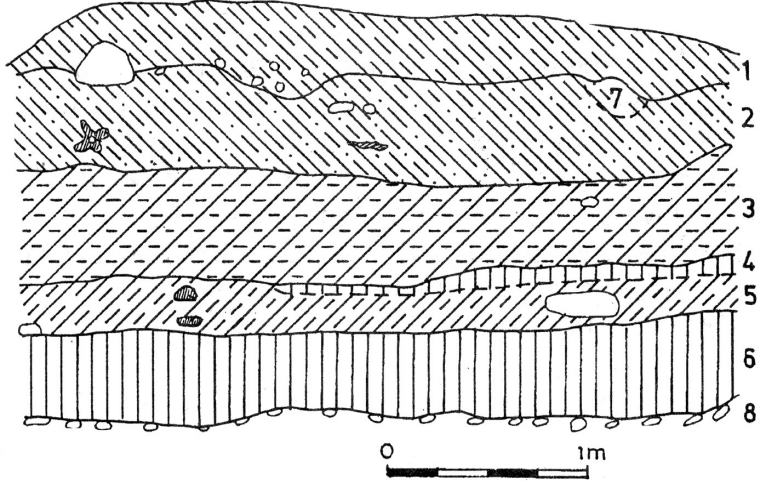

Fig. 11. South profile of the test pit Nr. 3 at Ostrovul Banului (Boroneant 1973c; Paunescu 2000): 1. brown-reddish soil of about 0.15-0.48 m-Level IV Mesolithic Schela Cladovei (Boroneant 1973c.8 refers to 'Epipaleolithic III'); 2. yellow-grey compacted soil of about 0.28-0.50 m-Level III Mesolithic Schela Cladovei (Boroneant 1973c.8 refers to 'Epipaleolithic IIIa'); 3. yellow-grey sandy soil of about 0.37-0.52 m-Level II Tardigravettian of Mediterranean type (Boroneant $1973 \mathrm{c} .8$ refers to 'Epipaleolithic II'); 4. clay sediment of about 0.05$0.12 \mathrm{~m}$; 5. light-yellow sandy soil of about 0.20$0.25 m$ - Level I Tardigravettian of Mediterranean type (Boroneant 1973 c.8 refers to 'Epipaleolithic I'); 6. dark-yellow soil of about 0.37-0.48 m, sterile; 7. gravel. Boroneant did not originally offer a scale (Boroneant 1973c), but Paunescu added one (Paunescu 2000).

tively reduced shore erosion, although it was obvious that the water had destroyed part of the site.

Archaeological work was begun in 1965 under Boroneant, and continued in 1967, 1968, and 1982. A second campaign was undertaken from 1991 to 1996 by a British team (Bonsall et al. 1997; Bonsall 2004; Bonsall et al. 1996b; Bonsall et al. 2000a; Bonsall et al. 2002). During the summer of 2002 the local authorities reinforced the shore, in an attempt to prevent its further erosion. Presently there is left an area about twice the size of a football field, which gradually has been occupied by the local people and used for gardens and small corn fields. The site is in great danger of being totally destroyed by the locals.

Schela Cladovei offers a number of advantages as a location. It is placed right on the river bank, which gently rises into a forested hill. At about $300 \mathrm{~m}$ up the hill there is a small spring that flows in seven smaller streams down into the Danube around and across the site, insuring fresh, clean water. Being placed at the eastern extremity of the Gorge, the site inhabitants could practically control access to and from the canyon. The surroundings consist of very low hills covered by rich, mixed vegetation offering food for humans and animals. The hills are very easy to cross by foot.

There are no pictures of the site before excavations began, but Paunescu mentions that it covered an area of about $2 \mathrm{~km}$ between the naval dock and a border patrol post (Boroneant 1990a; Paunescu 2000). The site was continuously affected by different construction projects such as installations of water abduction pipes, the transformation of the beach into a gravel and sand quarry, and other smaller or larger, and recently more or less permanent structures were built.

According to Boroneant (2000b), the site is divided into two sections, east ('Sector A') and west ('Sector B'), of the small creek that flows into the Danube. Although scant Mesolithic traces were found west of the creek, the actual Mesolithic habitation was found only on the area east of the creek, up to the proximity of a railway check point. A map of the excavations was published (Boroneant 2000b.277): in 'Sector B', during 1967-1968, excavations extended for about $140 \mathrm{~m}$ and a width of about $1.80 \mathrm{~m}-4 \mathrm{~m}$, depending of the sinuosity of the shore. During 1982-1989, apparently on the same $140 \mathrm{~m}$, excavations were extended into the shore to a depth of $4.50 \mathrm{~m}$. In 1990, excavations were performed west of the1968 area, on both sides of an access road from a closed gravel quarry. The total of area uncovered during this episode appears to be of about $30 \mathrm{~m}$ in length and $1.80 \mathrm{~m}$ to $6 \mathrm{~m}$ in width $(\mathrm{V} . \mathrm{BO}$ roneant and A. Boroneant, personal communication).

Paunescu (2000.449) inserts the observation that at least part of the faunal osteological material identified by Bartosiewicz (Bartosiewicz et al. 1995) has its provenance in amalgamated remains that strati-

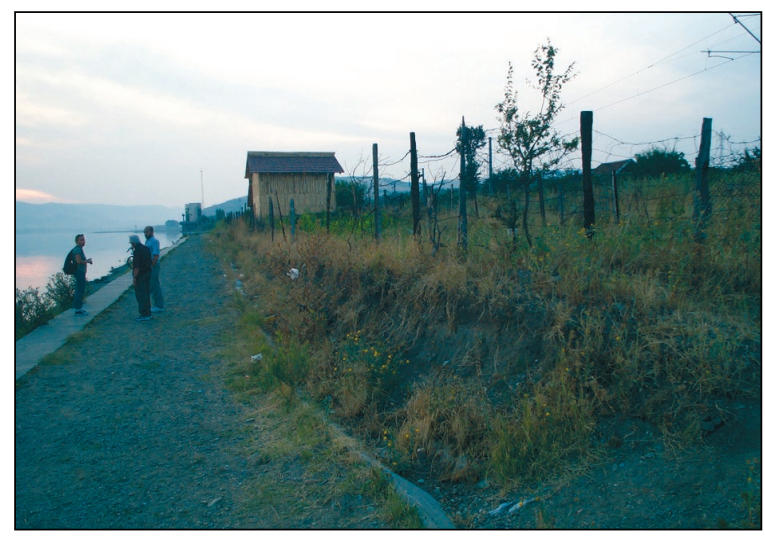

Fig. 12. The Schela Cladovei site, partly covered by vegetable gardens and corn plantations. 
graphycally have been almost impossible to separate by levels, and is therefore unsure.

Although comparable in importance with Lepenski Vir, before 1990 there were no radiocarbon dates for this site. Some dates were offered after 1990 (Bonsall 1997; Bonsall et al. 1996; Bonsall et al. 2004; Bonsall et al. 2000; Cook et al. 2002).

Stratigraphycally, there appears to be a level defined by Boroneant $(1973 c ; 2000 b)$ Epipalaeolithic II (the oldest), and one Epipalaeolithic I. The same author uses 'Schela Cladovei' (Boroneant 1973c.8) and 'Schela Cladovei II' (Boroneant 1973c.9), but it is impossible to determine if the former means Epipalaeolithic I and the latter Epipalaeolithic II, or vice versa. In the periodization offered by the same author, the Schela Cladovei site appears under Schela Cladovei culture phases II and III (Boroneant 1973c. 15). According to the fact the phase I of the periodization is the oldest, it may only be assumed that phase II is associated with Schela Cladovei II, or, Epipalaeolithic I, and phase II with Schela Cladovei I, or, Epipalaeolithic II. thers (Paunescu 2000) identify an oldest Tardigravettian level, and a second upper level of Mesolithic Schela Cladovei. There is no mention of an archaeological sterile dividing these two levels. In Paunescu's (2000.439) opinion, enumerating from upper to lower the cultural levels at Schela Cladovei, he notes level II, Mesolithic Schela Cladovei, the only level associated with this culture (according to Boroneanţ the Epipaaleolithic I, in other words Mesolithic II Schela Cladovei culture) and level I Epipalaeolithic Tardigravettian of Mediterranean type (according to Boroneanţ the Epipalaeolithic II, in other words Mesolithic I Schela Cladovei culture).

\section{Ostrovul Corbului}

The island of Ostrovul Corbului is $16 \mathrm{~km}$ upstream from Schela Cladovei on the Danube, between fluvial $\mathrm{Km} 911$ and 916. At the point where the Danube waters separate embracing the island, is Hinova village, and the point is called 'Botul Piscului'; again where the two branches of the Danube reunite there is the village of Baloti and the point is called 'Botul Cliuciului'. The excavations at Botul Cliuciului were conducted in two areas: A1, right at the point where the Great Danube (the main branch) and the Lesser Danube (the smaller branch) reunite, and A2, about $120 \mathrm{~m}$ upstream on the Greater Danube bank. Only in area A1 have Mesolithic Schela Cladovei remains been uncovered.

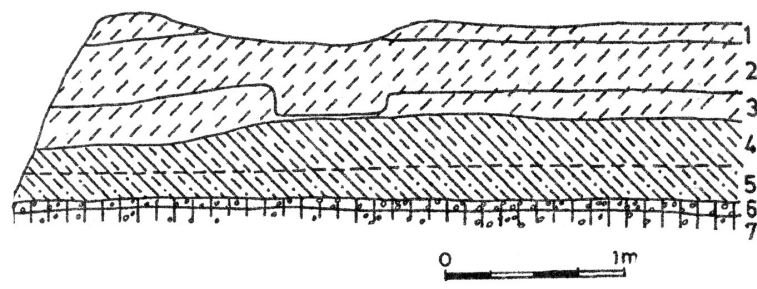

Fig. 13.The west profile of Section B1 at Schela Cladovei (Boroneant 1973c; 2000b; Paunescu 2000): 1. Humus, XVII-XIX cent. of about 0.12-0.16 m; 2. light-brown soil of about 0.25-0.38 m-Starčevo-Criş; 3. dusty dark yellow soil of about 0.150.25 m - Starčevo-Criş; 4. dark yellow dusty soil of about 0.12-0.30 m, Mesolithic Schela Cladovei (V. Boroneant 1973c.4 refers to 'Epipalaeolithic I'); 5. dusty light-yellow soil 0.16-0.20 m-Tardigravettian; 6. mud and stones layer of about 0.05-0.08 m; 7. gravel (V. Boroneant 1973 c.4 refers to 'Epipalaeolithic II'). A scale was not originally offered by Boroneanţ (1973c), but added by Paunescu (2000).

The excavators conducted a more careful and detailed excavation. As a result, the nature and the volume of information available from Ostrovul Corbului is far superior compared to any of the other Schela Cladovei sites.

One particular event occurred during excavations (Petre Roman, personal communication) not mentioned in any publications about this site. The management of the hydroelectric plant announced that a stop was going to be put on the water drainage for 4 hours. The excavation team took advantage of the lowering water level and were able to extend the excavation for almost $7 \mathrm{~m}$ into the riverbed, uncovering Mesolithic Schela Cladovei artefacts to a depth of about $-2 \mathrm{~m}$. The excavation map included the area (Paunescu 1996.71), but explanations were never offered in print.

There are a number of available stratigraphies for the Mesolithic sections. Here we will be present the ones most discussed by the excavators (Mogoseanu 1978; Paunescu 2000). According to all stratigraphic profiles (Mogoseanu 1978; Paunescu 1990; 2000; Roman 1987) there are two Mesolithic Schela Cladovei culture strata, not separated by archaeological sterile, and not preceded by an Epipalaeolithic layer. It appears that for archaeologists unfamiliar with the Romanian language, there is a recurring misunderstanding of one particular characteristic of Section XI (A-B). The section was excavated by Mogoseanu (1978), who uncovered seven fire hearths within the two Mesolithic Schela Cladovei levels. Four of these hearths, representing three superimposed levels of Mesolithic occupation, were uncovered in the 


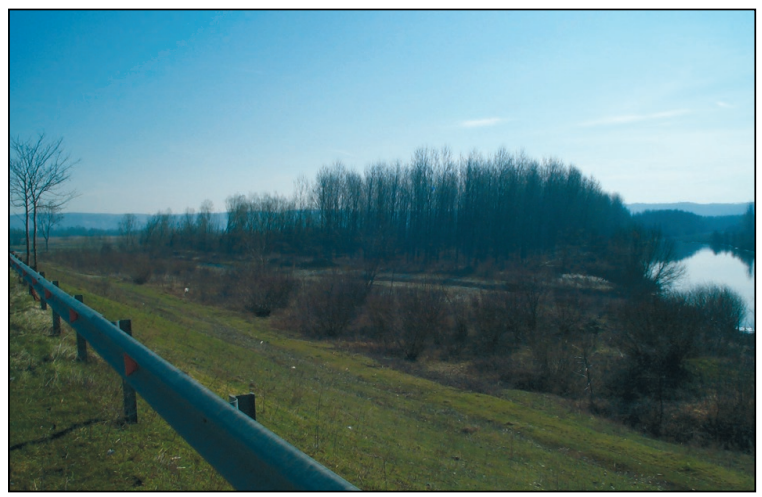

Fig. 14. Ostrovul Corbului at Botul Cliuciului. Excavations were covered by the dam and the road from where the picture was taken. On the right the Lesser Danube can be seen.

shelter or hut marked with a red $X$ in Fig. 15. There is one hearth at the bottom of the hut, one at a median level, and two at the upper level, separated by alluvial sediment suggesting powerful floods. Mogoseanu suggests that one and the same group of people built and rebuilt the first two levels of hearths, and a second group built the third, upper level of hearths. As a total, however, for the entire cultural deposition associated with Mesolithic Schela Cladovei culture, Mogoseanu specifies:

"In total, stratul de cultura Schela Cladovei, gros de circa $0.70 \mathrm{~m}$ (din care este exclusa adincimea locuintei) numara 7 nivele de locuire, fiecare nivel fiind marcat printr-o noua constructie de vatra de foc." [As a total, Schela Cladovei cultural level, about $0.70 \mathrm{~m}$ thick (from which the depth of the shelter is excluded) contains 7 levels of habitation, each being marked by a new construction of fire hearths.] (Mogoseanu 1978.339)

The three fire hearth levels associated with the shelter are considered to be two levels of occupation: the bottom two hearths one level, as constructed by the same group of people, and the upper hearths another level, built by a different group of people. The total of 7 levels of habitation consists of these two, plus 5 other fire hearths uncovered only on level I (phase I) Mesolithic Schela Cladovei (Fig. 15, excavation level 7; Fig. 16, excavation level 11), as explained by Paunescu (1996. 134-135). For the second phase of Mesolithic Schela Cladovei culture, only 3 hearths were uncovered, all in Section I (Fig. 16, excavation level
10). Fortunately, the excavators made available both the depths of the hearths and their association with phase I or II of Mesolithic Schela Cladovei, and the depths of the radiocarbon samples and their association with the phase I or II of this culture. Due to this fact, Ostrovul Corbului is the only site where it is possible to obtain a better evolutionary image of Schela Cladovei culture.

\section{Ostrovul Mare}

The island of Ostrovul Mare is the easternmost Mesolithic Schela Cladovei culture site. The island is engulfed by the Danube proper and a lesser branch of the river, called Dunarea Mica (Lesser Danube). It is $14.5 \mathrm{~km}$ long, and has a width varying between 3.2 $\mathrm{km}$ at Bivolari-Schela and $0.800 \mathrm{~km}$ at Padurea Mica.

The island has been excavated since the beginning of the century by numerous archaeologists, revealing remains belonging to the Neolithic, Bronze Age, Iron Age, Roman, and Medieval periods (Paunescu 2000). In 1978 Boroneant began to excavate at Danube Km 873 and 875 . Most unfortunately, the excavator never published articles dedicated entirely to this site, except for a preliminary report (Boroneant et al. 1979). Scant information and vague references were inserted in texts on the Schela Cladovei culture, providing a general description (Boroneant 1990; 1982; 1980; 1979).

The excavations were performed in two locations: Point Km. 873, and Point Km. 875. Information is tangential and extremely brief. There is no stratigraphic chart or specification on the depth of the strata. At both points there are two levels of Mesolithic Schela Cladovei culture, not separated by archaeological sterile (Paunescu 2000). According to the infor-

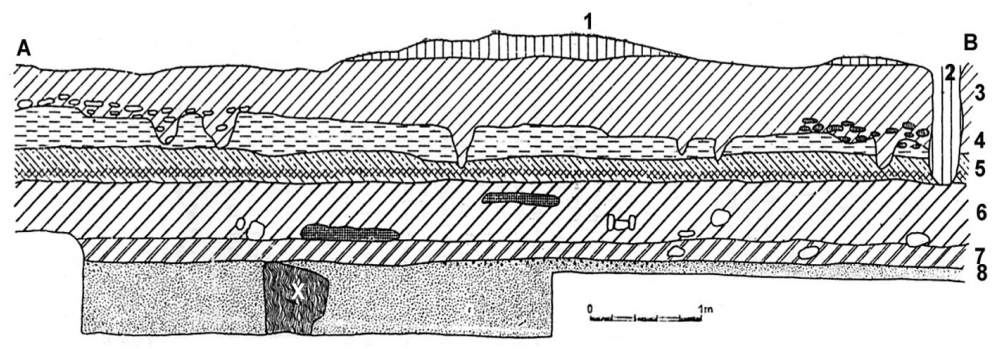

Fig. 15. South profile of Section XI (A-B) (Mogoseanu 1978; Paunescu 1990; 2000). 1. archaeologically sterile. 2. Neolithic Cotofeni hole; 3. grey yellow soil of about $2.63 m$ - Neolithic Salcuta; 4. Light brown layer of about $0.35 \mathrm{~m}$, archaeologically sterile; 5 . dark brown soil of about $0.25 m$ - Neolithic Starčevo-Criş; 6. black clay of about 0.45m - Level II Mesolithic Schela Cladovei; 7. Light brown soil of about 0.20m - Level I Mesolithic Schela Cladovei; 8. Alluvial material. White $X$ : hut. 
mation offered in this section, it is only possible to assume that by 'Paleolithique Supérieur' (Boroneant $2000 b$ ) Boroneant generally meant Epipalaeolithic; by Epipalaeolithic he generally meant Mesolithic; by 'Epipaleolithic I' he meant 'Mesolithic I'; and by 'Epipalaeolithic II' was meant 'Mesolithic II'. Considering also the fact that at some sites there were actual Epipalaeolithic I and II levels, this would translate chronologically as Epipalaeolithic, Mesolithic I, and Mesolithic II. According to other sources, 'Paleolithicque Supérieur' meant the Aurignacian from Baile Herculane-Pestera Hotilor, and by Epipalaeolithic is meant both the Tardigravettian and the Mesolithic as one cultural phenomenon (Boroneant, personal communication).

It has been suggested that at most Schela Cladovei sites there are two phases of occupation for Schela Cladovei Culture (Boroneant, personal communication) generally divided by an archaeological sterile layer. However, as shown in the published stratigraphies (Boroneant 1973c; 2000b; Paunescu 2000), it is not possible to distinguish an archaeologically sterile between the Mesolithic levels. Instead, in some cases there is such a stratum between an Epipalaeolithic level, sometimes called Tardigravettian of Mediterranean type, and the layers associated with Mesolithic Schela Cladovei culture. As can be seen, there is a major problem regarding stratigraphic explanations residing from a total lack of differentiation between such concepts as excavated layer, cultural layer, cultural phase. For instance, while Boroneant $(1973 a)$ refers to the Mesolithic deposits at Ostrovul Banului as 'Epipaleolithic IIIa' and 'Epipaleolithic IIIb', Paunescu (2000) refers to the same deposits as 'Ostrovul Banului level III' and 'Ostrovul Banului level IV'. Subsequently, in the same publication, Paunescu (2000.386) uses 'Ostrovul Banului IIIa' and 'Ostrovul Banului IIIb', and only one page further on (2000.387) refers only to 'Ostrovul Banului III'. Also Paunescu informs us that the samples for radiocarbon dating were collected by Boroneant from 'level III' (Paunescu 2000.67). The unanswered question: does 'level III' and 'Epipaleolithic IIIb' refer to the same cultural phase of Mesolithic Schela Cladovei culture at Ostrovul Banului?

\section{The 'tell' of the new radiocarbon dates}

All samples for the new AMS dates presented here (Tab.1) were obtained from strata associated with the remains of Mesolithic Schela Cladovei culture such as antler tools (Boroneant 1970; 1990b; 2000b) (Fig. 17) or lithics (Paunescu 2000).

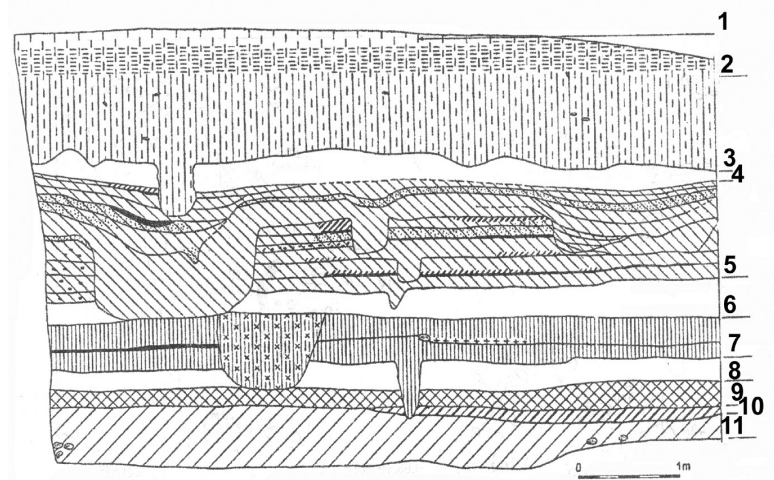

Fig. 16. Segment of the West profile of Section I (central) (Paunescu 1990; 2000): 1. modern deposition of unspecified depth; 2. unspecified soil of about 0.30m - Doco-Roman; 3. unspecified soil of about 0.90m - Bronze Age; 4. unspecified soil and depth - archaeologically sterile; 5 . unspecified soil of about 1.24m - Neolithic Cotofeni; 6. unspecified soil and depth - archaeologically sterile; 7. unspecified soil of about $0.60 m$ - Neolithic Salcuta; 8. unspecified soil and depth - archaeologically sterile; 9. unspecified soil of about $0.42 m$ - StarčevoCriş; 10. unspecified soil of about 0.34m - Level II Mesolithic Schela Cladovei; 11. light yellow clay of about 0.29m - Level I Mesolithic Schela Cladovei.

These dates confirm some of the facts suggested by the old dates obtained from Icoana (Tab. 2): the depth of the samples is not always in accordance with the age. This situation was signalled at an early stage of site analysis by the samples Bln-1078 and Bln-1077 at Icoana, as explained in the preceding section. The new dates put a particular accent on this site, suggesting that it may represent the oldest Mesolithic in the Iron Gates region, at least for the northern bank of the Danube; there is one date later than $8800 \mathrm{BC}$, twelve dates older than $8000 \mathrm{BC}$. In assigning two levels of Mesolithic at Icoana, Boroneant considered the fact that there were antler and wild boar canine tools in both levels, and that these tools were identical to those from the site at Schela Cladovei. No such tools were found in the Tardigravettian levels at Cuina Turcului or other Mesolithic Iron Gates sites, such as Ostrovul Banului.

As a consequence, if Boroneant was right in his judgment and there are indeed two Mesolithic levels at Icoana, it means that:

(1) a Mesolithic population showed up in the Danube Gorge immediately after $9000 \mathrm{BC}$, with an already well-defined antler and bone tool-making technology;

(2) these people were already adapted to an economy consisting of both intensive fishing and hunting; 

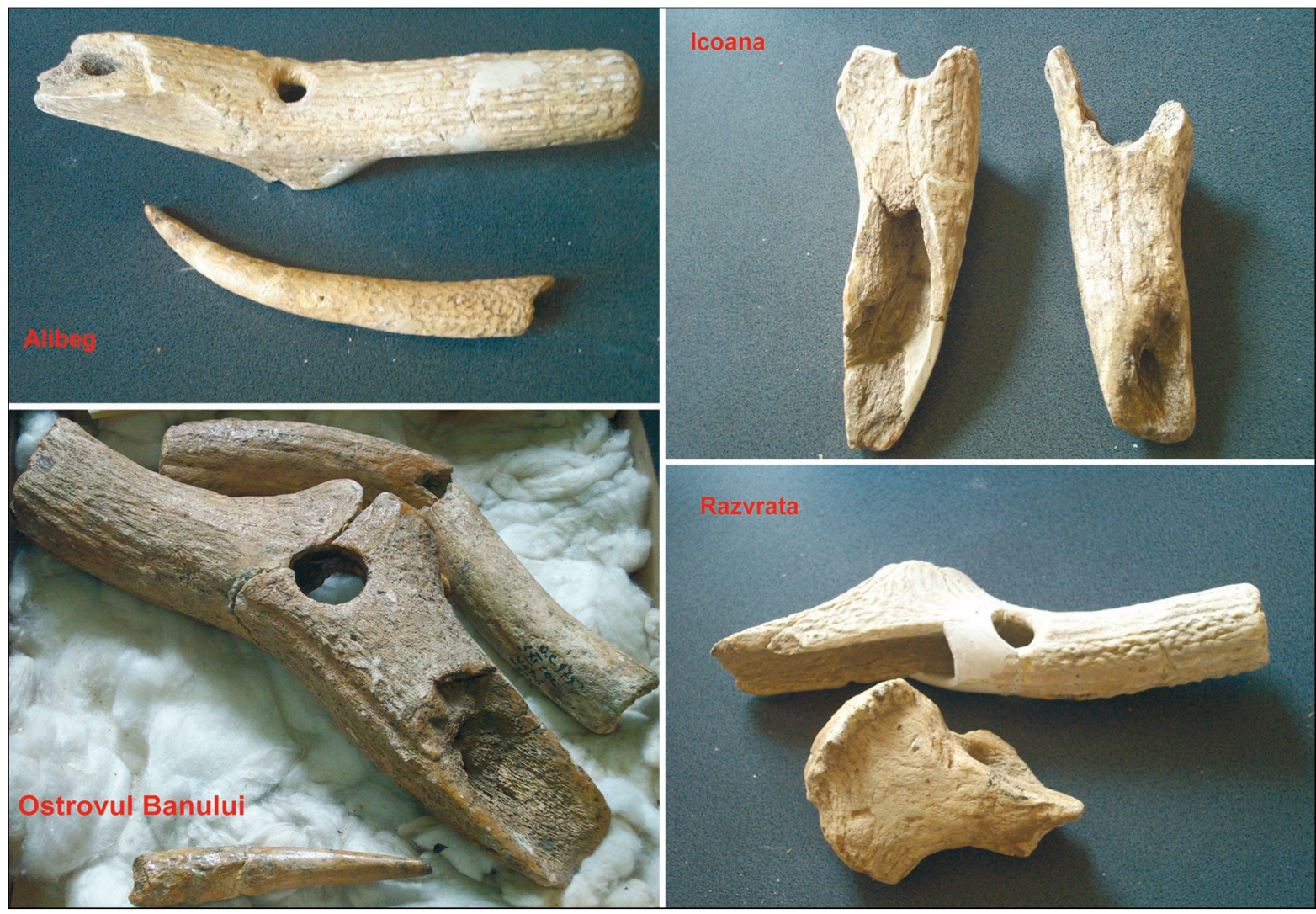

Fig. 17. Mesolithic Schela Cladovei antler tools from Razvrata, Icoana, Alibeg, and Ostrovul Corbului.

3 the antler and bone tool, and stone tool technologies were therefore not rooted in the previous Tardigravettian;

(4) by the time these people settled the Danube bank there may have been Tardigravettian groups inhabiting the river's defile, and these two cultures coexisted in parallel for some time. One of the three radiocarbon dates from the Tardigravettian layers (Mogoseanu 1978; Paunescu 2000) at Cuina Turcului (Fig. 1), a cave site where no remains associated with Mesolithic Schela Cladovei were uncovered (Paunescu 1970 ; 2000), shows a time range of $8175 \pm 200 \mathrm{BC}$ (Mogoseanu 1978.339). There are six date at Icoana older that $8200 \mathrm{BC}$. It is also possible that late Tardigravettian groups were present at Ostrovul Banului (Mogoseanu 1978).

Paunescu (2000.394-400) considers the lowest level at Icoana to be Tardigravettian, on the basis of the lithic technology of some 100 identifiable pieces. It has to be noted that, generally, the cultural remains of this level are scarce. However, there is one huge problem regarding the dates from Cuina Turcului. As shown above, Mogoseanu lists the date Bln-802 as $8175 \pm 200 \mathrm{BC}$. The same sample is presented by Paunescu (2000.342) as being dated $10125 \pm 200 \mathrm{BP}$. If
OxCal calibrated for one sigma, it shows a range of 10 150-9350 BC (68.2\%), or, about $9750 \pm 400$ BC, a time period far earlier than the one presented by Mogoseanu. There are no details offered by the Mogoseanu, therefore it is impossible to comment on his source for the calibration of this date. If the oldest date of about $8800 \mathrm{BC}$ is compared to the late date of about $9700 \mathrm{BC}$ from Cuina Turcului, there is a difference of about 900 years. Such a time span may be long enough, but all the same, short enough to leave room for speculation on the relationship between the final Tardigravettian and the early Mesolithic at Iron Gates.

One other significant fact revealed by the corroboration of the new and old dates from Icoana is the longevity of the site occupation from about $8800 \mathrm{BC}$ to perhaps $6000 \mathrm{BC}$. The long sequence of radiocarbon dates offers a most needed reference point for a comparison among all the Mesolithic sites on both sides of the Danube. There is one old radiocarbon date of about $4800 \mathrm{BC}$, which doubtlessly should not be associated with the Mesolithic period. Unfortunately, there are no details about the sample, but it appears that the cultural layer of its provenance should be associated with the Neolithic StarčevoCriş. 
It is impossible at this point to speculate on the nature of the site's occupation. It is more likely, however, that the site was not occupied permanently all year round. Considering its location and proximity to the site at Razvrata, it has been suggested that these were probably twin sites, probably outposts of a base-site located in the Mraconia River Depression (Fig.2) (Bolomey 1973) which is at present mostly under water. There are two new dates from Razvrata, both showing a time range of about $8100 \mathrm{BC}$, and an old one of about $6500 \mathrm{BC}$. The new dates make Razvrata one of the oldest Mesolithic sites on the northern shore of the Danube, and strongly suggest either a parallel, or an alternate coexistence with Icoana. It is simply impossible to say if people were moving back and forth between the two locations, or if they were actually living at the two locations at the same time, or both. It is clear, however, that the sites were contemporary, and that human activity at Razvrata lasted for a very long time. The stratigraphy of the site is identical to the one at Icoana, generating the same controversial interpretations. Probably the most interesting thing about the cultural development in the vicinity of the River Mraconia is the possibility that Icoana and Razvrata on the northern side of the Danube, and Hajdučka Vodenica (Fig. 2) on the southern side represent in fact a related cultural evolution. There are only a few dates from Hajdučka (Borić and Miracle 2004) ranging about 7400$8200 \mathrm{BC}$; the three sites appear to have been contemporary for some time. Again, according to the available data, it may not be possible yet to speculate if same group of people settled on both sides of the Danube at the mouth of the Mraconia, but according to the location of the sites, it is hard to believe that if inhabited at the same time, these people would have ignored each other. Also, according to some stable isotope results of human, animal, and snail shell, it appears that the Mesolithic people of Iron Gates did move up and down the defile at least to some degree. One great exception appears to be the inhabitants of the Schela Cladovei site. The values obtained from these individuals may be interpreted in a two ways: either people from along the Danube defile came over and settled at Schela Cladovei, or inhabitants of Schela Cladovei travelled intensively on the river (Dinu 2006). Hopefully, future research related to the human DNA of individuals uncovered on the both sides of the Danube (present authors; Dusan Borić, personal communication) will shed some light in this direction.

From Ostrovul Banului there is only one new radiocarbon date ranging around $7300 \mathrm{BC}$, which is some- how close to one of the old dates ranging around 7100 BC. A second old sample produced a date of about $6500 \mathrm{BC}$. Comparing these dates with the sequence from Icoana, it appears that at least at one point in time this site also represented a cultural development contemporary with the one present at the mouth of the Mraconia River. The new radiocarbon date is almost identical to one of the old dates from Ostrovul Corbului, and comparing all the dates from the two sites, they appear to cover the same period.

Considering also the four dates available from both Mesolithic levels at Ostrovul Corbului, it appears that these sites represent a later Mesolithic development at Iron Gates; and comparing them to the dates from Ostrovul Banului, it may be that the Mesolithic at the later site also represent a late phase in the defile. Ostrovul Banului is a site that, in corroboration with the information from Cuina Turcului and Icoana, may offer crucial information on the cultural sequences at Iron Gates. The Tardigravettian and the Mesolithic layers are well defined, allowing for a clear differentiation between the cultural layers and phases. However, the lack of more precise stratigraphic information does have an effect on the interpretation of the radiocarbon dates. The new date of about $7300 \mathrm{BC}$ was generated by a sample whose provenance context was surely Mesolithic, but whose depth was relatively low: only $-0.40 \mathrm{~m}$. According to the stratigraphic profile and the scale (Fig. 11) such a depth must be somewhere on the border between the first and the second phases of the Mesolithic. No details are available about the other two samples from Ostrovul Banului for a comparison. The new date of about $6800 \mathrm{BC}$ from Ostrovul Mare is currently the only one available, making any chronological speculation about this site impossible, other than that at one point it was contemporary with IcoanaRazvrata, Ostrovul Banului, Ostrovul Corbului, Schela Cladovei.

Interestingly, the eight new radiocarbon dates from Schela Cladovei, comprising a time span from about $7300 \mathrm{BC}$ to about $5700 \mathrm{BC}$ represent a perfect continuation of the dates offered previously (Cook et al. 2002) covering a range from about $7600 \mathrm{BC}$ to about $7400 \mathrm{BC}$, and offering a comparative reference for some 2000 years of cultural development. None of these 8 dates is older than about $7300 \mathrm{BC}$, which may confer some degree of confidence in considering Schela Cladovei a site that formed and developed at a much later time than Icoana, Razvrata, or the very little understood site of Alibeg. Equally im- 
portant, the date of $5725-5625 \mathrm{BC}$ generated by a sample from $-0.45-0.53 \mathrm{~m}$, may reflect the last period in the existence of the Mesolithic at Iron Gates. It has been suggested that the Neolithic Starčevo elements appeared in the region by $6070-5720 \mathrm{BC}$ (Bonsall et al. 2004). Considering some of the older dates, it has to be noted that offered more recently (Boroneant 2000.85-86) for Alibeg (Pescari-Coronini), of about $8410 \pm 100 \mathrm{BC}$, that appears to be less known to scholars interested in the Mesolithic and Mesolithic-Neolithic transition in Europe. Besides this date, there is another of about 6100-5980 BC (Paunescu 2000) according to which Alibeg was considered a very late site (Paunescu 2000; Prinz 1987; Radovanovic 1996a;1996b; Tringham 2000). The date of about $8400 \mathrm{BC}$ drastically changes this status, matching some of the oldest dates for Icoana, and making Alibeg one of the earliest Mesolithic sites at Iron Gates.

In summarizing the above information, a few ideas can be outlined. First, the chronological sequence at Icoana seems to cover most, if not the entire evolution of the Mesolithic at Iron Gates. It provides a comparative timetable for all the other sites on both banks of the Danube. Second, the new radiocarbon dates reshape the entire chronological sequence for the Mesolithic at Iron Gates. The sites at Icoana, Razvrata, and Alibeg appear to be much earlier than previously thought, substantially pushing back the time range for the appearance of the Mesolithic groups in the region. Third, the situation at IcoanaRazvrata and the early date from Alibeg raises some questions about the cultural sequence for all the Iron Gates Mesolithic sites:

(1) if there was a cultural continuity from Tardigravettian to Mesolithic, why would an abrupt change in the antler tools technologies occur by $8800 \mathrm{BC}$, and

(2) comparing the radiocarbon dates from Icoana, Alibeg and Cuina Turcului, it is very difficult to explain why perforated antler tools were present at Icoana by $8800 \mathrm{BC}$, but not present only a few hundred meters upstream at Cuina Turcului by about the same time. It must be underlined that no perforated antler tools were found in the level diagnosed as Mesolithic at Veterani Terasa. Of course, the discrepancy between the dates for the final Tardigravettian at Cuina Turcului must be also considered.

Fourth, the corroboration of the new and old dates raises some questions on the validity of the relative chronology on which previous periodization models were constructed, and the stratigraphic considerations on which these relative chronologies were based. There is an obvious discrepancy between some of the depths inscribed on the radiocarbon samples and the results. Although at present it is extremely difficult to reevaluate the stratigraphy at some of these sites, it is not impossible, and hopefully, future research will at least in part clarify this problem.

\section{Periodization: absolute and relative chronology}

Due to the fact that at present the archaeological material at most of the sites presented above, can only be analyzed according to the depth inscribed on it, and that the scale offered for each stratigraphic profile appears to be rather approximate and in some cases totally wrong, it is extremely challenging to determine where one particular sample actually came from. Moreover, in cases such as Icoana, early signs that the relative and absolute chronology were in total contrast as confirmed by Bln-1078 and Bln1077 were ignored. As a consequence, items found at a particular depth may have been interpreted as they belong to an earlier or later level of occupation, but generally the logic according to which, the upperyounger, and the lower-older, seems not to have been always true for a site like Icoana. Such being the situation at one site, questions may be raised about others excavated by the same archaeologist.

This situation is perpetuated mainly due to the periodization advanced by some Romanian archaeologists (Boroneant 1973c; Paunescu 2000) as a reflection of their views of the cultural evolution at Iron Gates. Some even advanced the hypothesis that there was an uninterrupted evolution from the Upper Paleolithic to Neolithic:

"If the Neolithic was introduced from outside, where did it come from? The present author believes that it did not come from outside... The present author believes that the discovery of clay baking and processing towards the end of the Epi-Paleolithic in this particular zone led to the abandonment of the processing of river boulders into artistic forms in favour of the processing of clay into pottery and idols." (Boroneant 1990b.479)

Such models, in which the evolution of Mesolithic Schela Cladovei culture is seen as a smooth linear evolution from local Tardigravettian developments and a basis for a locally evolving Neolithic (Boroneanţ 1973.15-16) were based on the interpretation 
of an earlier and a later phase of the Mesolithic at Iron Gates. Although similar in results, such models are in total contrast with those advancing the idea that in most cases the earlier Mesolithic level was in fact Tardigravettian (Paunescu 2000.40, 49, 52). Other authors are critical of these views (Mogoseanu 1978.345-340), considering the absence of some raw material as quartzite, art, and portable artefacts, and stratigraphy at sites such as Ostrovul Corbului. Such authors advanced hypotheses according to which the Mesolithic at Schela Cladovei could have originated rather the very late echoes of a Mousterian found at Baile Herculane-Pestera Hotilor (Fig. 1).

The absence of radiocarbon dating meant that these models had to be constructed mainly, and in some cases solely, on a parallel analysis of the archaeological material. Of all periodizations, the most influential is that offered by Boroneant (1973c), who explains that:

"La periodization de la culture Schela Cladovei procède des données fournies par sa structure matérielle et des modifications que cette-dernière a subies." (Boroneant 1973c.15)

According to such changes in the material culture, four stages of evolution were identified (Boroneant 1973.15):

1st stage and the oldest at Veterani Terasa; $2^{\text {nd }}$ stage at Icoana I, Razvrata, Schela Cladovei, Ostrovul Corbului IIIa; $3^{\text {rd }}$ stage at Icoana II, Schela Cladovei, Razvrata, Ostrovul Corbului IIIb; $4^{\text {th }}$ stage at Alibeg.

In the absence of radiocarbon dates from Veterani Terasa, it is not possible to make any references to this site. Considering only the absolute chronology offered by the new and old dates from the rest of the sites, it is possible, however, to offer a Mesolithic absolute chronology (Fig. 18), on approximately 500 year periods:

$1^{\text {st }}$ stage, about $8800-8300$ BC: Icoana, Alibeg, (Veterani Terasa?);

$2^{\text {nd }}$ stage, about $8300-7800$ BC: Icoana, Razvrata;

$3^{\text {rd }}$ stage, about 7800-7300 BC: Icoana, Schela Cladovei, Ostrovul Banului, Ostrovul Corbului;

$4^{\text {th }}$ stage, about 7300-6800 BC: Icoana, Ostrovul Banului, Schela Cladovei, Ostrovul Corbului, Ostrovul Mare;

$5^{\text {th }}$ stage, about $6800-6300 \mathrm{BC}$ : Icoana, Ostrovul Corbului, Ostrovul Banului;

$6^{\text {th }}$ stage, about 6300-6100 BC: Icoana, Alibeg; 7th stage, about 5700-4800 BC: Schela Cladovei, Icoana.

The cultural phases of the Mesolithic layer were not noted for reasons related to discrepancies between sample depth, dating results, and stratigraphic interpretations as explained earlier in this paper.

Paunescu's identification of a Tardigravettian layer at sites as Alibeg, Razvrata, Icoana, was based solely on lithic analysis, sometimes the entire sample consisting of a rather small number of pieces being accepted as reliable; at Razvrata, for instance, the lower Mesolithic level labeled as Tardigravettian yielded a total of 90 pieces (Paunescu 2000.393). All other cultural elements were largely disregarded. As a consequence, we have considered this interpretation as unreliable.

Considering the fact that the new radiocarbon samples were collected from depths associated with Mesolithic cultural remains, among which signature Schela Cladovei antler tools represent a noticeable reference point, the fact that such tools were not found in pre-Mesolithic cultural levels at any of the sites at Iron Gates, and that Boroneant constructed his judgments on the presence of Mesolithic cultural evidence, we tend to agree with his identification of two Mesolithic cultural layers at the sites presented in this paper. On the other hand, we tend to disagree with the Boroneant model of a local cultural and demographic continuity from the Upper Palaeolithic to the Neolithic. Rather, based on the data presented in this paper, we suggest that the Upper Palaeolithic, the Mesolithic, and the Neolithic at Iron Gates represent separate stages of cultural development, and that the human populations associated with these stages were not related in any way.

It is interesting to notice that the earliest Neolithic remains at Iron Gates were uncovered at none of the sites associated with the Mesolithic, but at Cuina Turcului Cave, and, contrary to what may be expected, that is not the earliest Neolithic Starčevo in Romania. The two known Early Neolithic sites north of the Danube appeared at Circea (Bolomey 1976; Nica 1976; 1977; 1993), and Gura Baciului (Biagi, Shennan and Spataro 2005; Biagi and Spataro 2005), rather far from the Iron Gates. There are no dates for Circea, but Gura Baciului produced a date of about $7140 \pm 45$ BP (Biagi et al. 2005.46). Calibrated 0xCal $(1 \sigma, 68.2 \%)$ the date ranges from $6055-5985 \mathrm{BC}$. Although there are no radiocarbon dates for the lowest Neolithic Starčevo levels at Cuina Turcului, the 
Starčevo ceramic appears to be clearly of a later Starčevo phase, associated by some with Starčevo-Criş IIA-IIB (Nica 1979.22).

Also contrary to expectations, the only Neolithic human remains, consisting of very few bones and skulls (Paunescu 1996.140) uncovered on the northern bank of the Iron Gates, came from Ostrovul Corbului (Necrasov and Botezatu 1981; Paunescu 1996), and not from large, complex Mesolithic sites such as Schela Cladovei. Unfortunately, the Neolithic human remains from Ostrovul Corbului have been not dated.

Comparing the radiocarbon date from Gura Baciului with the new and old dates listed in this paper, it is not difficult to see that there is only a date from Schela Cladovei, of about 57255625 BC (Tab. 1), and one from Icoana later than 5000 $\mathrm{BC}$, that may be associated with the appearance of the Starčevo culture on the northern shore of the Danube at Iron Gates. Also, considering the ceramic typology and its association with a later phase of Starčevo, the date of 61205980 BC from Alibeg may still be too early to be connected in any way with possible Mesolithic-Neolithic contacts in the region. It may be said, therefore, with a fair degree of confidence, that the radiocarbon dates presented in this study rather infirm the hypothesis of Mesolithic-Neolithic contacts at Iron Gates.

\section{Conclusions}

The data presented in this paper is of dual importance: it reconfigures the absolute chronology for the Mesolithic at Iron Gates, and it raises some questions about the stratigraphic interpretation of the sites discussed here.

Although the new radiocarbon dates shed new light on the evolution of the Mesolithic on the northern bank of the Danube, there are still numerous gaps that may produce surprises. More dates are needed from sites at Ostrovul Mare, Ostrovul Banului, and Veterani Terasa in order to better understand the evolutionary trajectory of the Mesolithic at Iron Gates. The dates presented in this paper shed some light on the Mesolithic cultural trajectory at Iron Gates, but also raise questions about the beginning and the end of this period. For these questions to be answered at least in part, it is absolutely necessary for more radiocarbon dates to be obtained from the Tardigravettian levels at Ostrovul Banului, and the Neolithic site of Circea, the Neolithic human remains from Ostrovul Corbului, and from samples stratigraphically associated with the Starčevo ceramic at Cuina Turcului.

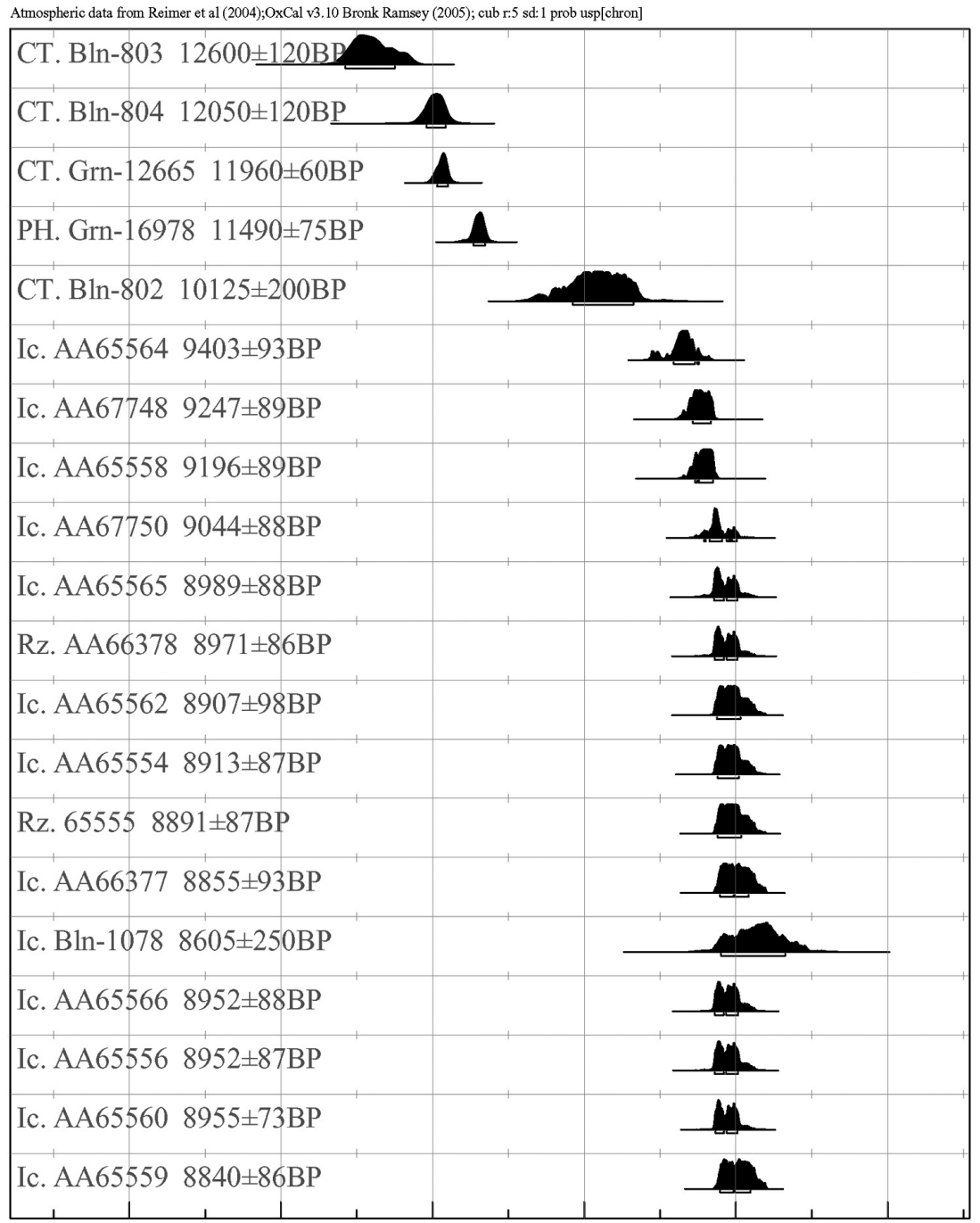

$16000 \mathrm{CalBC} 14000 \mathrm{CalBC} 12000 \mathrm{CalBC} 10000 \mathrm{CalBC} 8000 \mathrm{CalBC} 6000 \mathrm{CalBC}$ Calibrated date

Fig. 18. Radiocarbon dates from sites discussed in this paper: CT, Cuina Turcului; PH, Pestera Hotilor - Baile Herculane; Rz, Razvrata; Ic, Icoana; SC, Schela Cladovei; OB, Ostrovul Banului; OC, Ostrovul Corbului; OM, Ostrovul Mare; Al, Alibeg; GB, Gura Baciului. 
Fortunately, the site at Schela Cladovei is still accessible for future archaeological excavation. It appears, however, that the huge importance of this site in the general context of the European Mesolithic and Mesolithic-Neolithic transition is either not understood, or absolutely ignored by the Romanian forums; if no drastic measures for salvaging it are taken soon, it may be lost forever. Whereas it is not excluded that more Mesolithic sites are waiting to be discovered in places like Ostrovul Corbului and Ostrovul Mare, the complexity of Schela Cladovei, comparable only with
Lepenski Vir, makes it unique among all the Mesolithic sites in Southeastern Europe and beyond.

$$
\text { ACKNOWLEDGEMENTS }
$$

Many thanks to Adina Boroneant who provided all of the samples for the new radiocarbon dates, as well as a great volume of information about the sites discussed here. Without her help, this paper could have never been written.

\section{REFERENCES}

BARTOSIEWICZ L., BONSALL C., BORONEANŢ V. and STALLIBRASS S. 1995. Schela Cladovei: A Review of the Prehistoric Fauna. Mesolithic Miscellany 16: 2-19.

2001. New Data on the Prehistoric Fauna of the Iron Gates: A Case Study from Schela Cladovei, Romania. In R. Kertesz and J. Makkay (eds.), From Mesolithic to Neolithic. Budapest. Akaprint: 15-21.

BIAGI P., SHENNAN S. and SPATARO M. 2005. Rapid Rivers and Slow Seas? New Data for the Radiocarbon Chronology of the Balkan Peninsula. Prehistoric Archaeology $\&$ Anthropological Theory and Education 6-7: 41-52.

BIAGI P. and SPATARO M. 2005. New Observations on the Radiocarbon Chronology of the Starčevo-Criş and Koros Cultures. Prehistoric Archaeology \& Anthropological Theory and Education 6-7: 35-40.

BOLOMEY A. 1973. An Outline of the Late Epipaleolithic Economy at the Iron Gates: The Evidence of Bones. Dacia 17: 41-52.

1976. Pe Marginea Analizei Arheoosteologice a Materialului de la Carcea-Dolj. Studii si Cercetari de Istorie Veche si Arheologie 27: 765-476.

BONSALL C., BORONEANŢ V. and SREJOVIĆ D. 1996. AMS Radiocarbon Determinations on Human Bone from Lepenski Vir, Vlasac and Schela Cladovei. Mesolithic Miscellany 17: 6-10.

BONSALL C., COOK G., LENNON R., HARKNESS D., SCOTT M., BARTOSIEWICZ L. and MCSWEENEY K. 2000. Stable Isotopes, Radiocarbon and the Mesolithic-Neolithic Transition in the Iron Gates. In M. Budja (ed.), $7^{\text {th Neolithic Stu- }}$ dies. Documenta Praehistorica XXVII: 119-132.

BONSALL C., COOK G, T., HEDGES R. E. M., HIGHAM T. F. G., PICKARD C. and RADOVANOVIĆ I. 2004. Radiocarbon and Stable Isotope Evidence of Dietary Change from the Mesolithic to the Middle Ages in the Iron Gates: New results from Lepenski Vir. Radiocarbon 46: 293-300.

BONSALL C., MACKLIN M. G., PAYTON R. W. and BORONEANT A. 2002/3. Climate, Floods, and River Goods: Environmental Change and the Meso-Neolithic Transition in Southeast Europe. Before Farming 4: 1-15.

BONSALL C., ROSEMARY L., MCSWEENEY K., CAROLINA S., DOUGLASS H., BORONEANT V., BARTOSIEWICZ L., ROBERT P. and CHAPMAN J. 1997. Mesolithic and Early Neolithic in the Iron Gates: A Paleodietary Perspective. Journal of European Archaeology 5: 50-92.

BORIĆ D. 1999. Places that Created Time in the Danube Gorges and Beyond, c. 9000-5500 BC. In M. Budja (ed.), $6^{\text {th }}$ Neolithic Studies. Documenta Praehistorica XXVI: 41-70.

2001. Mesolithic and Early Neolithic Hunters and Fishers in the Danube Gorges: An Analysis of Zooarchaeological Data. In R. Kertesz and J. Makkay (eds.), From the Mesolithic to the Neolithic. Budapest: Akaprint: 101-124.

2002. The Lepenski Vir Conundrum: Reinterpretation of the Mesolithic and Neolithic Sequences in the Danube Gorges. Antiquity 76: 1026-1039.

2004. Is the Mesolithic-Neolithic Subsistence Dichtonomy Real? New Stable Isotope Evidence from the Danube Gorges. European Journal of Archaeology 7: 221-248.

2005. Deconstructing Essentialisms: Unsettling Frontiers of the Mesolithic-Neolithic Balkans. In D. Bailey, A. Whittle and V. Cummings (eds.), (un)settling the Neolithic. Oxbow Books, Oxford: 16-31. 
BORIĆ D. and MIRACLE P. 2004. Mesolithic and Neolithic (Dis)continuities in the Danube Gorges: New AMS Dates from Padina and Hajdučka Vodenica (Serbia). Oxford Journal of Archaeology 23: 341-371.

BORONEANT A. and DINU A. 2007. The Romanian Mesolithic and the Transition to Farming. Studii de Preistorie 3/2005-2006: 41-76.

BORONEANŢ V. 1970. La Periode Epipaleolithique sur la Rivier Roumaine des Portes de Fer du Danube. Prehistorische Zeischrift 45: 1-25.

1973a. Apercu de la Culture Epipaleolithique Schela Cladovei. In Actes du V-ieme Congress International des Sciences Prehistoriques, Belgrade, 1973a., vol. VII: $165-172$.

1973b. Inceputurile Cultivarii Pamintului in Zona Portilor de Fier. Terra Nostra III: 115-123.

1973c. Recherches Archaeologiques sur la Culture Schela Cladovei de la Zone des 'Portes de Fer'. Dacia 17: 140-181.

1980. Betrachtung uber das Epipaleolitikum (Mesolithikum) in Romanien. In Mesolithikum in Europa. 2-nd Internationales Symposium Posdam, 1980. Verffentlichungen des Museums fur Ur-un Fruhgeschichte Potsdam 14/15: 289-294.

1990a. Le Site de Schela Cladovei: Problemes Pose par la Transition de la Culture Criș-Starčevo a la Culture Vincea. In D. Srejović and N. Tasić (eds.), Vincea and its World. Serbian Academy of Sciences and Art. Belgrade: $147-153$.

1990b. Thoughts on the Chronological Relations Between the Epi-Paleolithic and the Neolithic of the Low Danube. In C. Bonsall (ed.), The Mesolithic in Europe. John Donald, Edinburgh: 475-480.

1999. The Mesolithic Habitation Complexes in the Balkans and the Danube Basin. on-line </livingpast/nr1/ Boronean_/mesolithic.htm>.

2000a. Arheologia Pesterilor si Minelor din Romania. cIMeC. Bucharest.

2000b. Paleolithique Superieur et Epipaleolithique dans la Zone des Portes de Fer. Bucharest: SILEX.

BORONEANT V., BONSALL C., MCSWEENEY K., ROBERT P. and MACKLIN M. G. 1995. A Mesolithic Burial Area at Schela Cladovei, Romania. In A. Thevenin (ed.), L'Europe des Derniers Chasseurs: Epipaleolithique et Mesolithique. Actes du 5-e Colloque International UISPP (Commission 12), Grenoble, 18-23 September 1995. Paris: 385-390.
BORONEANT V. and BORONEAT C. 1983. Consideratii Asupra Parametrilor Tehnico-Functionali ai Uneltelor Preistorice de Lucrat Pamintul. Ialomita 1: 115-122.

BORONEANT V., CRACIUNESCU G. and STINGA I. 1979. Raport Preliminar Privind Sapaturile de la Ostrovul Mare. Materiale si Cercetari Arheologice XII: 17-18.

BORONEANT V. and NICOLAESCU-PLOPSOR D. 1990. Lesion Traumatiques Violents Datant de L'Epipaleolithique Tardif du Sou-Ouest de la Roumanie. Anthropologie XXVIII: 55-65.

C.S.A., C. d. S. a. A. 1967. Dunarea Intre Bazias si Cetatea Izmail. Bucuresti: Institutul de Studii si Cercetari Hidrotehnice.

COOK G. T., BONSALL C., HEDGES R. E. M., MCSWEENEY K., BORONEANT V., BARTOSIEWICZ L. and PETITTE P. B. 2002. Problems of Dating Human Bones from the Iron Gates. Antiquity 76: 77-85.

DAVIDESCU M. 1965. 0 Asezare de Tip Criş la Turnu-Severin. Revista Muzelor III: 547-549.

DINU A. 2006. The Question of Pig Domestication at Mesolithic Iron Gates. Ph.D. Dissertation, University of Wisconsin in Madison, Dpt. of Anthropology.

DINU A., MEIGGS D., BALASESCU A., BORONEANT A., SOFICARU D. A. and MIRITOIU N. 2006. On Men and Pigs: Were Pigs Domesticated at Mesolithic Iron Gates of the Danube? Part One: Teeth Metrics. Studii de Preistorie 3/ 2005-2006: 77-98.

Grupul de Cercetari Complexe, P. d. F. 1976. Geografia. Bucuresti: Grupul de Cercetari Complexe 'Portile de Fier'. Editura Academiei Republicii Socialiste Romania.

I.G.G.A.R.S.R. 1969. Geografia Vaii Dunarii Romanesti. Bucuresti: Institutul de Geologie si Geografie al Academiei Republicii Socialiste Romania. Editura Academiei Republicii Socialiste Romania.

LARSON G., DOBNEY K., ROWLEY-CONWY P., SCHIBLER J., TRESSET A., VIGNE J.-D., EDWARDS C. J., SCHLUMBAUM A., DINU A., B ĂLĂEÇSCU A., DOLMAN G., TAGLIACOZZO A., MANASERYAN N., MIRACLE P., VAN WIJNGAARDEN-BAKKER L., MASSETI M., BRADLEY D. G., COOPER A. and ALBARELLA U. 2007. Pigs, Ancient DNA and the Origins of Neolithic Farming in Europe. Proceedings of the National Academy of Sciences 104(39): 15276-15281.

LAZAROVICI G. 1979. Neoliticul Banatului. Biblioteca Muzei Napocensis. Cluj.

MIRITOIU N., SULTANA N. M. and SOFICARU A. D. 2004. Asupra Unui Craniu Prehistoric dintr-o Descoperire Intim- 
platoare de la Schela Cladovei. Studii de Preistorie 2: 47-73.

MOGOSEANU F. 1978. Mezolithicul de la Ostrovul Corbului, o Noua Asezare de tip Schela Cladovei. Studii si Cercetari de Istorie Veche si Arheologie 29: 335-351.

NECRASOV O. and BOTEZATU D. 1981. Les Caracteristiques Anthropologiques d'un Squelette Decouvert a Ostrovul Corbului, Appartenant a L'Aspect Culturel Schela Cladovei. Annuaire Roumain Anthropologique 18: 1114.

NICA M. 1976. Circea, cea mai Veche Asezare Neolitica de la Sud de Carpati. Studii si Cercetari de Istorie Veche si Arheologie 27: 435-463.

1977. Nouvelles Donnees sur le Neolithique Ancien d'Oltenie. Dacia XXI: 13-53.

1993. Citeva Date Despre Necropola Eneolitica de la Garlesti. Arhivele Olteniei (Serie Noua) 8: 3-17.

NICOLAESCU-PLOPSOR C. S. 1965. Epipaleolitic sau Mezolitic. 0 Problema de Terminologie? Studii si Cercetari de Istorie Veche 16: 765-773.

PAUNESCU A. 1970. Epipaleoliticul de la Cuina TurculuiDubova. Studii si Cercetari de Istorie Veche si Arheologie 21: 3-47.

1987. Les Industries Lithiques du Neolithique Ancien de la Roumanie et Quelques Considerations sur l'Inventaire Lithique des Cultures du Neolithique de Cette Contree. In W. University and J. U. Cracow (eds.), Chipped Stone Industries of the Early Farming Cultures in Europe. Wydawnictwa Uniwersytetu Warszawskiego, Warsaw: 75-94.

1990. Ostrovul Corbului. Verlag Caro. Bucuresti.

1996. Ostrovul Corbului. Verlag Caro. Bucuresti.

2000. Paleoliticul si Mezoliticul din Spatiul Cuprins Intre Carpati si Dunare. Editura AGIR, Bucuresti.
2001. Paleoliticul si Mesoliticul din Spatiul Transilvanean. Editura AGIR, Bucuresti.

PRINZ B. 1987. Mesolithic Adaptations on the Lower Danube. Vlasac and the Iron Gates Gorge. BAR International Series 330.

RADOVANOVIĆ I. 1996a. The Iron Gates Mesolithic. Archaeological Series 11: International Monographs in Prehistory.

1996b. Mesolithic-Neolithic Contacts: A Case of the Iron Gates Region. Poročilo o raziskovanju paleolitika, neolitika in eneolitika $v$ Sloveniji XXIII: 39-48.

1999. Neither Person nor Beast - Dogs in the Burial Practice of the Iron Gates Mesolithic. In M. Budja (ed.), $\sigma^{\text {th }}$ Neolithic Studies. Documenta Praehistorica XXVI: 71-87.

RADOVANOVIĆ I. and VOYTEK B. 1997. Hunters, Fishers or Farmers: Sedentism, Subsistence, and Social Complexity in the Djerdap Mesolithic. Analecta Praehistorica Leidensia 29: 1931.

ROMAN P. 1987. Dspre Istoricul Cercetarilor si Stratigrafia Unor Asezari din Ostrovul Corbului. Studii si Cercetari de Istorie Veche si Arheologie 38: 335-365.

SREJOVIĆ D. 1965. Lepenski Vir - A New Prehistoric Culture in the Danubian Region. Archaeologia Jugoslavica 7: $13-18$.

1990. The Mesolithic of Serbia and Montenegro. In C. Bonsall (ed.), The Mesolithic in Europe. John Donald Publishers LTD, Edinburgh: 481-491.

TRINGHAM R. 2000. Southeastern Europe in the Transition to Agriculture in Europe: Bridge, Buffer, Mosaic. In T. D. Price (ed.), Europe's First Farmers. Cambridge University Press, Cambridge: 19-56.

VOYTEK B. and TRINGHAM R. 1990. Rethinking the Mesolithic: The Case of South-East Europe. In C. Bonsall (ed.), The Mesolithic in Europe. John Donald Publishers LTD, Edinburgh: 492-499. 